\title{
Dietary-induced negative energy balance has minimal effects on innate immunity during a Streptococcus uberis mastitis challenge in dairy cows during midlactation
}

\author{
K. M. Moyes, ${ }^{*} \dagger$ J. K. Drackley,† J. L. Salak-Johnson,† D. E. Morin, $\ddagger$ J. C. Hope,§ and J. J. Loor ${ }^{*}{ }^{1}$ \\ *Mammalian NutriPhysioGenomics, \\ †Department of Animal Sciences, and \\ ¥College of Veterinary Medicine, University of Illinois, Urbana 61801 \\ §Institute for Animal Health, Compton, Near Newbury, Berkshire RG20 7NN, United Kingdom
}

\section{ABSTRACT}

Ten multiparous Holstein cows were used to determine the effects of negative energy balance (NEB) on the immune response to a Streptococcus uberis (strain O140J) mastitis challenge during midlactation. Before the study, milk from all quarters of each cow was bacteriologically negative, with a composite somatic cell count of $<200,000$ cells $/ \mathrm{mL}$. Cows were paired based on parity, days in milk, and milk yield. At approximately $77 \mathrm{~d}$ in milk, half the cows $(\mathrm{n}=5)$ were feed-restricted to $60 \%$ of calculated net energy for lactation requirements to induce NEB. Feed restriction lasted $7 \mathrm{~d}$. Control cows $(\mathrm{n}=5)$ were fed the same diet ad libitum (i.e., positive energy balance; PEB). After $5 \mathrm{~d}$, one rear quarter in all cows was inoculated with $5,000 \mathrm{cfu}$ of Strep. uberis. Jugular blood and aseptic quarter milk samples were collected daily until inoculation and every $6 \mathrm{~h}$ postinoculation for $36 \mathrm{~h}$. Blood was analyzed for nonesterified fatty acids, $\beta$-hydroxybutyrate, insulin, cortisol, albumin, serum amyloid A (SAA), and haptoglobin (Hp). Periodically throughout the trial period, blood neutrophils were isolated for determination of cell morphology, chemotaxis, and phagocytosis capability in vitro. Quarter milk samples were analyzed for concentrations of SAA, Hp, cytokines (tumor necrosis factor- $\alpha$, IL-10 and IL-1 $\beta$ ), and activity of respiratory burst enzymes (superoxide dismutase and glutathione peroxidase). All cows developed local and systemic signs of mastitis and calculated NEB was similar to that of cows experiencing postpartal NEB. Serum glucose and insulin concentrations increased in both groups after challenge, most likely because of enhanced glycogenolysis and gluconeogenesis; results indicate that immune cell function may be glucose dependent. Serum cortisol concentration was higher in NEB than PEB cows dur-

Received February 27, 2009.

Accepted May 15, 2009.

${ }^{1}$ Corresponding author: jloor@illinois.edu ing feed restriction only (before inoculation), and serum albumin concentration was higher in NEB than PEB cows during the infection period. Compared with PEB, cows in NEB had lower SAA concentrations in serum after $5 \mathrm{~d}$ of feed restriction but higher SAA concentrations in milk after Strep. uberis challenge. Serum Hp concentration was higher by $36 \mathrm{~h}$ postchallenge in NEB than in PEB cows. Phagocytic capability of neutrophils was lower in NEB than in PEB cows at $0 \mathrm{~h}$ of infection but decreased in both PEB and NEB cows through $36 \mathrm{~h}$ postinfection. Our results indicate that cows subjected to dietary-induced NEB during midlactation had relatively minimal alterations in immune function.

Key words: energy balance, mastitis, immunity, dairy cow

\section{INTRODUCTION}

During the periparturient period, dairy cattle are at a greater risk for developing diseases and disorders such as milk fever, mastitis, ketosis, retained placenta, laminitis, and abomasal displacement (Drackley, 1999). This periparturient period generally encompasses the last 2 to 3 wk of gestation through the first 2 to 3 wk of lactation (Drackley, 1999). During this time, essentially all cows experience some degree of NEB because of the lag in feed intake relative to increased energy demands for growth of the fetus and uterus, parturition, and milk synthesis, especially in high-producing cows (Drackley, 1999). The severity and duration of negative energy balance (NEB) is reflected in the degree of increase in circulating NEFA and BHBA and the degree of decrease in glucose concentrations (Drackley, 1999). Evidence indicates that cows experiencing a more severe degree of NEB may be more susceptible to mastitis (Suriyasathaporn et al., 1999; Perkins et al., 2002). However, increased circulating glucocorticoid concentrations in response to changes in physiological state and parturition likely contribute to the immunosuppression and increased susceptibility to mastitis normally observed 
during the periparturient period (Mehrzad et al., 2001). Therefore, dietary-induced NEB in midlactation dairy cows has been a useful model that mimics naturally occurring NEB while negating the hormonal and physiological changes that contribute to immunosuppression during the periparturient period.

Although several studies have reported impairment of immune function in conjunction with increased concentrations of ketone bodies in vitro (Hoeben et al., 1997; Suriyasathaporn et al., 1999), only a few studies have examined the relationship between energy balance and immune system function in vivo. Kremer et al. (1993) compared the severity of experimentally induced Escherichia coli mastitis in multiparous ketonemic and nonketonemic cows and observed that the ketonemic cows experienced more severe mastitis. In support of this finding, more recent results from large-scale studies of naturally occurring mastitis by Jánosi et al. (2003) and Nyman et al. (2008) observed that NEFA and BHBA, both indicators of NEB and hyperketonemia, are associated with the risk of mastitis during early lactation. However, the mechanisms behind this relationship are unclear.

To identify the mechanistic links among NEB, immune system function, and susceptibility to mastitis, several researchers have used dietary-induced NEB models in midlactation dairy cows. Perkins et al. (2002) fed midlactation cows to either $80 \%$ of maintenance requirements to induce NEB $(\mathrm{n}=6)$ or at ad libitum DMI to maintain positive energy balance (PEB; $\mathrm{n}=$ 6) and determined responses to intramammary infusion of $E$. coli LPS. Feed restriction did not influence serum tumor necrosis factor- $\alpha$ (TNF- $\alpha)$, total blood leukocyte concentration, or milk Ig concentration. However, feed-restricted cows did not develop a state of NEB (average of $-6.2 \mathrm{Mcal} / \mathrm{d}$ ) as pronounced as that normally observed in cows during early lactation (e.g., $-12.9 \mathrm{Mcal} / \mathrm{d}$; Rastani et al., 2001), which may partly explain the lack of effects observed.

To our knowledge, little is known regarding the relationship between NEB and susceptibility to Streptococcus uberis-associated mastitis. Streptococcus uberis is recognized as one of the major mastitis-causing pathogens and, as such, is a good candidate for use in investigating the effect of energy balance on the innate immune response during an IMI (Jayarao et al., 1999). Our hypothesis was that cows during dietaryinduced NEB would experience an impaired immune function that would result in a more severe degree of Strep. uberis-associated mastitis when compared with PEB cows. Accordingly, our objective was to determine the effect of NEB on the innate immune response to a Strep. uberis IMI challenge in multiparous Holstein dairy cows fed to $60 \%$ of $\mathrm{NE}_{\mathrm{L}}$ requirements. Midlacta- tion cows were used to avoid confounding influences on immune function in periparturient cows while inducing a similar degree of NEB. A wide range of serum, milk, and cellular indicators of immune function was evaluated.

\section{MATERIALS AND METHODS}

All procedures involving animals received approval from the Institutional Animal Care and Use Committee at the University of Illinois at Urbana-Champaign (protocol 05179).

\section{Animals and Diets}

Ten multiparous Holstein cows past peak lactation ( $>60 \mathrm{~d}$ postpartum) were used for this study. A primary objective was to evaluate the effect of NEB on large-scale mammary tissue gene expression using a transcript profiling approach (data to be presented elsewhere), and the chosen number of animals $(\mathrm{n}=10)$ was sufficient to detect statistical differences (Tempelman, 2005). Recent studies with objectives similar to ours showed that 6 cows per treatment was a sufficient number to detect metabolic differences between cows subjected to dietary-induced NEB versus cows in PEB during midlactation, as well as to detect clinical signs of inflammation (Perkins et al., 2002).

To be eligible, cows must have exhibited PEB for $>2$ consecutive weeks with composite milk SCC $<200,000$ cells $/ \mathrm{mL}$, and cows must not have been treated for clinical signs of mastitis or any other disease during early lactation. Because composite rather than quarter foremilk samples were collected, all quarters from all cows must have been bacteriologically negative to confirm that no quarters were subclinically infected with an invading pathogen. Eligible cows were paired based on parity, DIM, and milk yield. Cows were housed and fed in individual tie stalls, had free access to water, and were milked twice daily at 0500 and $1700 \mathrm{~h}$. Cows averaged $39.2 \pm 7.4 \mathrm{~kg}$ of milk/d and were $77 \pm 12 \mathrm{DIM}$ at the start of the trial.

The 28-d experiment consisted of 3 phases (Figure 1). Phase 1 was a 14-d adjustment period during which feed intake, daily milk production, and milk composition were measured. Phase 2 involved $7 \mathrm{~d}(168 \mathrm{~h})$ of feed restriction with an IMI Strep. uberis challenge $132 \mathrm{~h} \mathrm{(5.5}$ d) after the beginning of feed restriction. Phase 3 was an 8-d realimentation period. During phase 1 , all cows were fed a TMR for ad libitum intake (Table 1). The TMR was balanced to meet NRC (2001) requirements for cows producing approximately $40 \mathrm{~kg}$ of milk/d. Cows were fed to ensure $10 \%$ daily refusals and daily DMI was measured by the differences in feed offered 
Table 1. Ingredient and nutrient composition (DM basis) of the experimental diet

\begin{tabular}{|c|c|}
\hline Item & Amount, $\%$ of dietary DM \\
\hline \multicolumn{2}{|l|}{ Ingredient } \\
\hline Corn silage & 27.9 \\
\hline Alfalfa silage & 14.6 \\
\hline Alfalfa hay & 5.46 \\
\hline Cottonseed & 6.14 \\
\hline Corn, ground & 21.9 \\
\hline Corn distillers grain, wet & 14.9 \\
\hline Soybean hulls & 4.02 \\
\hline Lactating cow supplement $^{1}$ & 5.14 \\
\hline \multicolumn{2}{|l|}{ Nutrient content $^{2}$} \\
\hline $\mathrm{CP}$ & 15.7 \\
\hline $\mathrm{ADF}$ & 27.1 \\
\hline $\mathrm{NDF}$ & 39.9 \\
\hline $\mathrm{NE}_{\mathrm{L}}, \mathrm{Mcal} / \mathrm{kg}$ & 1.59 \\
\hline
\end{tabular}

${ }^{1}$ Contained (as-fed basis) $10.07 \%$ limestone, $5.03 \%$ dicalcium phosphate, $16.10 \%$ sodium bicarbonate, $2.35 \%$ salt, $6.71 \%$ biotin, $2.35 \%$ magnesium oxide, $50.32 \%$ soybean meal- $48,0.02 \%$ rumensin premix (i.e., $320 \mathrm{mg} / \mathrm{d}$; Elanco Animal Health, Division of Eli Lilly Canada Inc., Guelph, Ontario, Canada), $3.36 \%$ urea ( $45 \%$ N), and $3.69 \%$ vitamin-mineral supplement (contained a minimum of $5.0 \% \mathrm{Mg}, 7.5 \% \mathrm{~K}$, $10.0 \% \mathrm{~S}, 2.0 \% \mathrm{Fe}, 3.0 \% \mathrm{Zn}, 40 \mathrm{mg} / \mathrm{kg}$ of Co, $5,000 \mathrm{mg} / \mathrm{kg}$ of $\mathrm{Cu}, 250$ $\mathrm{mg} / \mathrm{kg}$ of I, $150 \mathrm{mg} / \mathrm{kg}$ of Se, 2,200 kIU/ $\mathrm{kg}$ of vitamin A, $660 \mathrm{kIU} / \mathrm{kg}$ of vitamin D, 22,000 IU $/ \mathrm{kg}$ of vitamin $\mathrm{E}$ ).

${ }^{2}$ Nutrient content was based on means calculated from the analysis of the TMR on a monthly basis.

and refused. Samples of the TMR, individual forages, cottonseed, concentrate mixes, and orts were collected weekly and analyzed for DM content (AOAC, 1995). As-fed formulations of TMR were adjusted weekly, if necessary, to account for changes in DM content of forages. The TMR was sampled monthly and analyzed by wet chemistry methods for CP, NDF, and ADF (Dairy One Cooperative Inc., Ithaca, NY). The TMR was mixed once daily, with approximately half the ration fed at $1100 \mathrm{~h}$ and the remainder fed at $1700 \mathrm{~h}$.

During phase 2, cows within a pair were randomly assigned to either the PEB $(\mathrm{n}=5)$ treatment or the NEB $(\mathrm{n}=5)$ treatment. Cows in the PEB group continued to be fed for ad libitum intake, whereas cows in the $\mathrm{NEB}$ group were restricted to $60 \%$ of calculated $\mathrm{NE}_{\mathrm{L}}$ requirements based on $\mathrm{BW}$, milk production, and milk composition. The dietary treatments were continued for $7 \mathrm{~d}(168 \mathrm{~h})$. After $3 \mathrm{~d}(72 \mathrm{~h})$, the amount of feed offered to the NEB cows was adjusted to maintain energy intake at $60 \%$ of $\mathrm{NE}_{\mathrm{L}}$ requirements to accommodate decreases in milk yield and BW.

During phase 3, NEB cows were returned to full feed and antibiotic therapy was administered to treat the Strep. uberis infection for $8 \mathrm{~d}$. All cows were withheld from the synchronized breeding program until after completion of the study. No cows displayed signs of estrous during the experimental period. To comply with the standard herd protocol, all cows continued to receive subcutaneous injections of recombinant bST (rBST; Posilac, Monsanto Co., St. Louis, MO). The experimental phases were scheduled such that rBST injections were administered on d 12 of phase 1 and d 5 of phase 3 to minimize any potential confounding effects of rBST on immune response (Burvenich et al., 1999) during phase 2.

\section{Calculation of Energy Balance}

To calculate energy balance, BW was measured weekly, DMI was recorded once daily, and milk production was recorded at both daily milkings. In addition, morning and evening composite milk samples were collected and pooled, based on a weighted average of milk produced at each milking; these samples were analyzed for true protein, fat, MUN, SCC, TS, and SNF (Dairy Lab Services, Inc., Dubuque, IA).

Daily DMI and calculated $\mathrm{NE}_{\mathrm{L}}$ density of the TMR were used to determine calculated daily $\mathrm{NE}_{\mathrm{L}}$ intake (Mcal/d) for each cow. Energy requirements for maintenance were calculated according to NRC equations $(\mathrm{NRC}, 2001)$, where requirement $=\left[\mathrm{BW}(\mathrm{kg})^{0.75}\right] \times$

Phase 2:

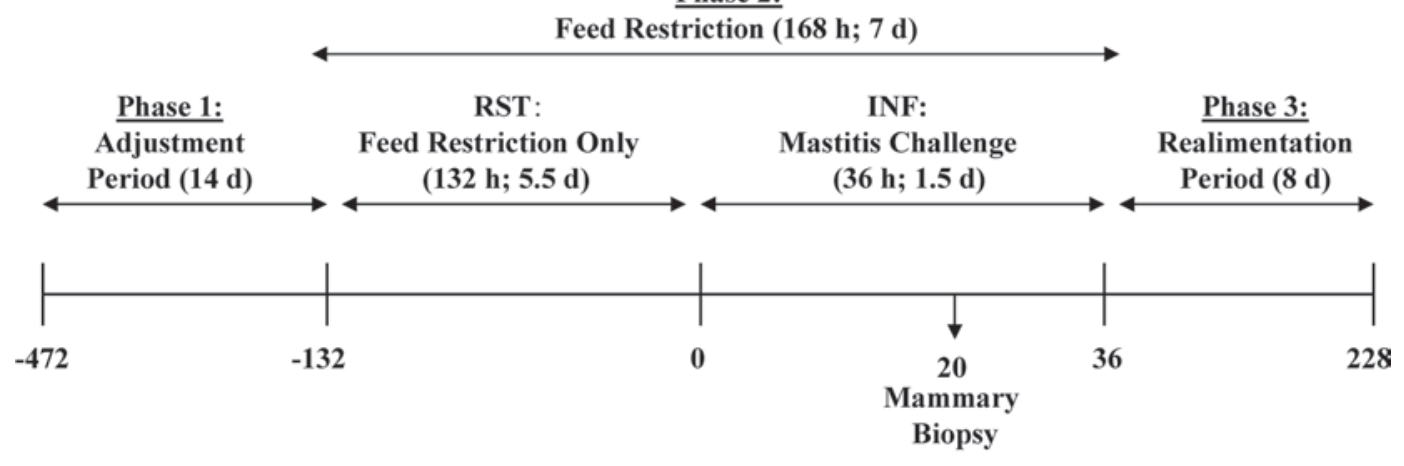

Hour Relative to Inoculation $(\mathrm{h}=0)$

Figure 1. Trial timeline for phases 1 to 3 . 
$[0.08 \mathrm{Mcal} / \mathrm{kg}]$. Energy requirements for milk production $(\mathrm{NRC}, 2001)$ were calculated as $\mathrm{NE}_{\mathrm{L}}(\mathrm{Mcal} / \mathrm{kg})=$ $[(0.0929 \times \%$ fat $)+(0.0547 \times \%$ protein $)+(0.0395$ $\times \%$ lactose $)$, and energy balance $(\mathrm{Mcal} / \mathrm{d}$ ) was calculated as $\left[\mathrm{NE}_{\mathrm{L}}\right.$ intake - (maintenance energy + milk energy output)].

\section{Intramammary Challenge with Strep. uberis (0140J)}

Streptococcus uberis strain O140J (provided by J. Hogan, The Ohio State University, Wooster) was stored at $-80^{\circ} \mathrm{C}$ until use. Before inoculation, a $10-\mu \mathrm{L}$ loopful of colonies was incubated in $100 \mathrm{~mL}$ of Todd-Hewitt broth for $6 \mathrm{~h}$ at $37^{\circ} \mathrm{C}$. After incubation, the broth culture was diluted in sterile Mammalian Ringer's Solution (Electron Microscopy Sciences, Hatfield, PA) to yield approximately 5,000 $\mathrm{cfu}$ in a $2-\mathrm{mL}$ volume (i.e., 2,500 $\mathrm{cfu} / \mathrm{mL})$.

One day before the IMI challenge, foremilk samples from all quarters of each cow were cultured (see below) and confirmed to be bacteriologically negative. After the afternoon milking on $\mathrm{d} 5$ (132 $\mathrm{h} ; \mathrm{h}=0$ of infection) of feed restriction, $2 \mathrm{~mL}$ of inoculum containing Strep. uberis was infused into one rear quarter of each cow via a sterile disposable syringe fitted with a sterile teat cannula using the full insertion infusion method. Before inoculation, challenged teats were rigorously cleaned with cotton balls containing $70 \%$ isopropyl alcohol. Immediately after inoculation, all teats were immersed in a postmilking teat disinfectant containing $1 \%$ iodine with lanolin. Starting at $36 \mathrm{~h}$ postinoculation, after all samples had been collected, infected quarters were aseptically infused with $125 \mathrm{mg}$ of ceftiofur $\mathrm{HCl}$ (SpectraMast LC, Pfizer Animal Health, Kalamazoo, MI) once daily for 8 consecutive days. During the first $3 \mathrm{~d}$ of antibiotic treatment, cows also were administered $60 \mathrm{~mL}$ of procaine penicillin $\mathrm{G}(300,000 \mathrm{IU} / \mathrm{mL}$, i.m.; US Vet, Hanford Pharmaceuticals, Syracuse, NY) twice daily. This regimen resulted in clinical and bacteriological cures, with bacteriological cure confirmed by repeated culturing of mammary secretions. Biopsies of mammary tissue from both rear quarters of all cows (i.e., infected and noninfected quarters) were obtained $20 \mathrm{~h}$ postchallenge for measurements not reported here.

\section{Indicators of Clinical Disease}

Health Examinations. A variety of systemic and local inflammatory indicators were used to monitor the clinical response to IMI Strep. uberis challenge. These included rectal temperature, heart rate, and respiration rate at $0,3,6,12,14,16,18,20,24,30,36,42$, and $48 \mathrm{~h}$ postchallenge. Infected mammary quarters were assessed for redness, heat, pain, and swelling, and for color, viscosity, and consistency of milk (Morin et al., 1998). Based on previous experience, inoculation with this dose and strain of Strep. uberis was expected to result in transient fever, tachycardia, tachypnea, firm mammary glands, and visible changes in mammary secretions, with systemic signs peaking 18 to $24 \mathrm{~h}$ postinoculation (Morin et al., 2003).

Milk SCC and Bacteriological Examinations. Before feed restriction and immediately before challenge, duplicate samples of quarter foremilk were aseptically collected for analysis of SCC and bacteriological status. Samples were stored at $4^{\circ} \mathrm{C}$ and analyzed within 3 d. In addition, quarter milk samples were collected at 12 and $20 \mathrm{~h}$ postchallenge to quantify SCC and at $12,20,24,30$, and $36 \mathrm{~h}$ postchallenge to quantify growth of Strep. uberis. The SCC was determined using infrared procedures (Foss 4000, Dairy Lab Services Inc., Dubuque, IA). Foremilk samples for culture were collected aseptically according to National Mastitis Council (2004) recommendations. These samples (100 $\mu \mathrm{L}$ ) were plated using the swirl plate method onto blood agar (trypticase soy agar with 5\% defibrinated sheep blood) and MacConkey agar plates (Remel Inc., Lenexa, KS) using a sterile, disposable L-shaped cell spreader. If needed, the samples were serially diluted with $1 \times$ PBS (pH 7.4; Sigma-Aldrich Co., St. Louis, $\mathrm{MO}$ ) to facilitate colony counting. Milk was allowed to dry before inverting the plates. Inoculated plates were incubated aerobically at $37^{\circ} \mathrm{C}$ in approximately $30 \%$ humidity for a maximum of $48 \mathrm{~h}$ and analyzed for the presence of mastitis-causing pathogens, including Strep. uberis, Streptococcus agalactiae, Staphylococcus aureus, yeast, Prototheca spp., Corynebacterium bovis, E. coli, and Klebsiella spp. (National Mastitis Council, 2004). Colonies of Strep. uberis were counted and bacterial concentrations in milk were calculated.

\section{Preparation of Whey Samples}

Whey was prepared using methods described by Bannerman et al. (2004) with minor modifications. Approximately $50 \mathrm{~mL}$ of quarter foremilk was collected from both rear quarters of all cows at 0,12 , and 20 $\mathrm{h}$ postchallenge before the mammary biopsies were performed. Milk was centrifuged at 44,000 $\times g$ for 30 min and the fat layer was removed. The skimmed milk was then decanted into a clean tube and centrifuged at $44,000 \times g$ for $30 \mathrm{~min}$. The supernatant was collected and filtered through a sterile, disposable, mixed cellulose ester membrane syringe filter $(25 \mathrm{~mm}, 0.45-$ $\mu \mathrm{m}$ diameter; Fisher Scientific, Pittsburgh, PA). The filtered whey sample was then stored at $-80^{\circ} \mathrm{C}$ until analysis for immune system parameters as described below. 


\section{Blood Collection}

Throughout the study period, jugular blood samples were collected by venipuncture daily before the morning feeding and then every $6 \mathrm{~h}$ after inoculation. Blood was drawn into evacuated tubes (Becton Dickinson Vacutainer Systems, Franklin Lakes, NJ) containing $\mathrm{K}_{3}$ EDTA or sodium heparin for plasma, or into evacuated serum separator tubes for serum. Plasma tubes were placed on ice until centrifugation $(1,300 \times g$ for 10 min at $4^{\circ} \mathrm{C}$ ); the plasma was aliquoted into microcentrifuge tubes and stored at $-20^{\circ} \mathrm{C}$ until further analysis. Serum tubes were allowed to clot for $30 \mathrm{~min}$ at room temperature and then centrifuged for $15 \min (1,300 \times$ $g$ at $22^{\circ} \mathrm{C}$ ). Serum was aliquoted into microcentrifuge tubes and stored at $-20^{\circ} \mathrm{C}$ until further analysis.

At $-132,-84,0,12,24$, and 36 h relative to inoculation $(\mathrm{h}=0)$, blood PMNL were isolated and chemotactic ( $\mathrm{K}_{3}$ EDTA tubes) and phagocytic capability (sodium heparin tubes) were determined in vitro (see below).

\section{Sample Analysis}

Energy Metabolites. Serum aliquots were analyzed via automated methods (Roche Hitachi 917 Autoanalyzer, Roche Diagnostics Corp., Indianapolis, IN) using commercially available kits. Samples were analyzed for concentrations of total cholesterol (Cholesterol/HP kit, Roche Diagnostics Corp.), albumin (a negative acutephase protein; Albumin Plus kit, Roche Diagnostics Corp.), glucose (Glucose/HK kit, Roche Diagnostics Corp.), BHBA (Ranbut kit, Rondox Laboratories Lit., Oceanside, CA), NEFA (NEFA C kit, Wako Chemicals, Dallas, TX), and triglycerides (TG; TG kit, Roche Diagnostics Corp.).

Hormones and Acute-Phase Proteins. Serum samples were analyzed for insulin using an RIA kit (Coat-A-Count Insulin kit; Diagnostic Products Corporation, Los Angeles, CA), as modified by Studer et al. (1993). Serum cortisol concentrations were analyzed using an RIA kit according to the manufacturer's recommendations with minor modifications (Coat-A-Count Cortisol kit, Diagnostic Products Corporation). For serum samples containing low concentrations of cortisol, 3 additional points on the calibration curve (13.8, 6.9 , and $3.45 \eta \mathrm{mol} / \mathrm{L}$ ) were added via serial dilution of the $\mathrm{B}$ calibrator $(27.6 \eta \mathrm{mol} / \mathrm{L})$ in the $\mathrm{A}$ calibrator (0.0 $\eta \mathrm{mol} / \mathrm{L})$ according to manufacturer's recommendations. Serum and whey samples were analyzed for serum amyloid A (SAA) and haptoglobin (Hp) using commercially available kits following the manufacturer's instructions (TriDelta phase SAA ELISA Assay and Hp Assay kit, respectively, Tridelta Development Limited, Dublin, Ireland). For the SAA assay, serum and whey samples were diluted 1:500 and 1:25, respectively, in sample diluent buffer before analysis.

Enzymes, Cytokines, and Isolation of Neutrophils, Morphology, Phagocytosis, and Chemotaxis. Whey samples from infected quarters were analyzed for activities of superoxide dismutase (SOD) and glutathione peroxidase (GPX) using commercially available test kits following the manufacturer's recommendations (SOD Assay kit and GPX Assay kit, respectively, Cayman Chemical, Ann Arbor, MI).

A detailed description of the laboratory procedures for cytokines and PMNL isolation, morphology, phagocytosis, and chemotaxis is provided in the online data supplement (http://jds.fass.org/content/vol92/ issue9/).

\section{Statistical Analysis}

Milk SCC, colony-forming units of Strep. uberis, and cells migrating in the chemotaxis assay were transformed to $\log _{10}$ values for statistical analysis. Data for this study were analyzed at the cow (i.e., blood, composite milk, energy balance, and health examination parameters) and quarter levels (i.e., quarter SCC, colony-forming units of Strep. uberis, and whey analyses) using the MIXED procedure of SAS, version 9.1 (SAS Institute, 2003) with the repeated measure of hour relative to IMI Strep. uberis challenge. Data were analyzed separately during 1) the feed restriction period (RST; prechallenge) and 2) the infection period (INF; postchallenge). During data analysis of the RST period only, $\mathrm{h}=0$ of restriction (i.e., $-132 \mathrm{~h}$ relative to IMI challenge) was used as a covariate. Cows were blocked based on day of inoculum administration (n $=2$ ). The random effect of pair nested within block was used as the error term in the REPEATED statement. The model was used to determine the effect of treatment (TRT; PEB or NEB) on energy balance, hormones, and immune system parameters both before (i.e., RST) and after (i.e., INF) IMI challenge with Strep. uberis. The class variables included cow, treatment, pair, block, covariate (RST period only), quarter (quarter level analysis only), and hour relative to IMI challenge. The model included TRT, hour, and the TRT $\times$ hour interaction. The degrees of freedom were estimated with the Kenward-Roger specification in the model statement. Data are presented as least squares means and SEM. Separation of least squares means for significant effects was accomplished using the Tukey option within the MIXED procedure of SAS. Statistical differences were declared as significant and highly significant at $P<0.05$ and $P<0.01$, respectively. Trends toward significance are discussed at $P<0.10$. 


\section{RESULTS}

\section{Indicators of Energy Balance}

Figure 2 shows the differences in serum metabolite concentrations in NEB and PEB groups relative to IMI challenge. All time points reflect samples collected from cows before the morning feeding, except for $0 \mathrm{~h}$, which was before the afternoon milking and after feed was offered. Cows assigned to the NEB treatment had higher circulating NEFA $(P<0.001$; Figure $2 \mathrm{~A})$ and BHBA concentrations $(P<0.001$; Figure 2B) than PEB cows. During the RST period, serum glucose concentrations were lower $(P<0.001)$ at $-12 \mathrm{~h}$ relative to IMI challenge for NEB than for PEB cows, which resulted in an overall TRT effect $(P<0.01$; Figure $2 \mathrm{C})$. The difference in serum glucose concentrations at $-12 \mathrm{~h}$ relative to IMI challenge was influenced by a large increase in glucose for one cow assigned to the PEB diet; therefore, differences may not have reflected overall TRT effects. During the INF period, overall serum glucose concentrations tended to be lower in NEB cows (TRT $P=0.07$ ) when compared with PEB cows, but no differences $(P$ $>0.10$ ) between NEB and PEB groups were observed at any given time point. Regardless of TRT, serum glucose concentrations increased $(P<0.001)$ by $36 \mathrm{~h}$ postinoculation when compared with $\mathrm{h}=0$. During the RST period, serum TG and cholesterol concentrations were higher $(P<0.05)$ at $-84 \mathrm{~h}$ when compared with $-132 \mathrm{~h}$ (i.e., before feed restriction; Figure $2 \mathrm{D}$ and $2 \mathrm{E}$, respectively). This led to an overall TRT effect $(P<$ 0.001 ) for both serum TG and cholesterol concentrations. During the INF period, serum TG concentrations were higher $(P<0.001)$ at $12 \mathrm{~h}$ relative to IMI challenge in NEB compared with PEB cows and resulted in an overall TRT effect $(P<0.001)$. During the INF period, serum cholesterol concentrations were not different (TRT $P=0.21$ ) between NEB and PEB cows and the TRT $\times$ hour interaction was not significant $(P=0.32)$. At $-84 \mathrm{~h}$ (i.e., $48 \mathrm{~h}$ after the start of feed restriction), a marked (TRT $\times$ hour $P<0.05$ ) decrease in serum albumin was observed within the NEB cows compared with the PEB cows (Figure 2F), but this did not lead to an overall TRT effect during the RST period (TRT $P=0.35$ ). After $12 \mathrm{~h}$ of IMI challenge, serum albumin was higher (TRT $\times$ hour $P<0.001)$ in NEB than PEB cows.

As expected, daily DMI (Figure 3A) and energy balance (Figure 3B) were lower (TRT $P<0.001$ ) for NEB cows than for PEB cows during both the RST and INF periods. All cows assigned to the NEB treatment were in NEB at the time of inoculation as well as after IMI challenge. Daily milk yield (Figure 3C) was significantly lower at $-84 \mathrm{~h}$ relative to IMI challenge in NEB than in PEB cows, which led to an overall TRT effect $(P<$ $0.01)$.

Figure 4A shows serum insulin concentrations, collected before the morning feeding, relative to IMI challenge. Insulin was lower $(P<0.01)$ in NEB cows than in PEB cows during both the RST and INF periods because of differences among treatments at -84 (RST) and 12 and $36 \mathrm{~h}$ postinoculation. Insulin concentrations reflected, to some extent, the decrease in serum glucose observed in the NEB cows relative to PEB cows (Figure 2C). Regardless of TRT, both serum insulin and glucose concentrations were higher $(P<0.001)$ at $36 \mathrm{~h}$ postinoculation than at $0 \mathrm{~h}$, indicating that glucose and insulin increased in response to IMI challenge. At $36 \mathrm{~h}$ after IMI challenge, the increased response of insulin to IMI challenge was more prominent in PEB cows $(P<$ $0.001)$ than in NEB $(P<0.05)$ cows compared with 0 $\mathrm{h}$, even though glucose concentrations were not different between TRT groups at this time.

Differences in milk composition between NEB and PEB cows during the RST period only are shown in the online data supplement available at http://jds. fass.org/content/vol92/issue9/ (Supplemental Figure $1)$. Because of side effects of the mammary biopsies, milk composition was not analyzed for all cows during the INF period. Milk fat yield (Supplemental Figure 1A), MUN concentrations (Supplemental Figure 1D), and TS yield (Supplemental Figure 1E) were not different $(P>0.10)$ between TRT groups. Milk protein $(P$ $<0.05$; Supplemental Figure 1B), lactose $(P<0.01$; Supplemental Figure 1C), and SNF (Supplemental Figure 1F; $P<0.05$ ) yields were lower for NEB cows than for PEB cows mainly because of effects observed at $-84 \mathrm{~h}$.

\section{Serum Cortisol}

For serum cortisol concentrations, (Figure 4B), the effect of hour and the TRT $\times$ hour interaction were significant $(P<0.05 ; P<0.001$, respectively) during the RST period mainly because of differences relative to $-132 \mathrm{~h}$. In NEB cows, serum cortisol concentrations were higher $(P<0.001)$ at $-84,-36$, and $-12 \mathrm{~h}$ than at $-132 \mathrm{~h}$ relative to IMI challenge (i.e., before feed restriction). This response led to an overall tendency $(P=0.06)$ for greater cortisol during the RST period in NEB versus PEB cows $(490 \pm 175$ and $335 \pm 177$ $\eta \mathrm{mol} / \mathrm{L}$, respectively). During the INF period, serum cortisol concentrations were no longer elevated in the NEB cows compared with PEB cows. No differences in serum cortisol concentrations were observed because of TRT, hour, or the TRT $\times$ hour interaction during the INF period. 
A

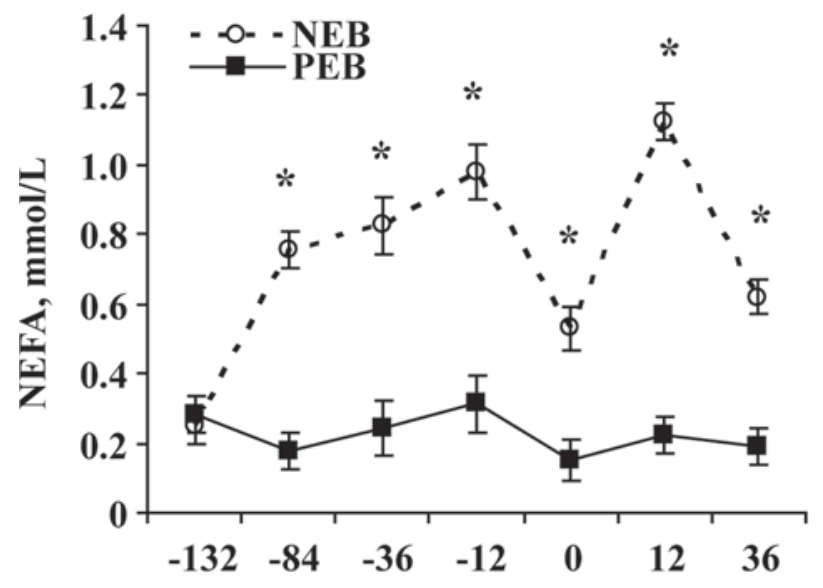

C

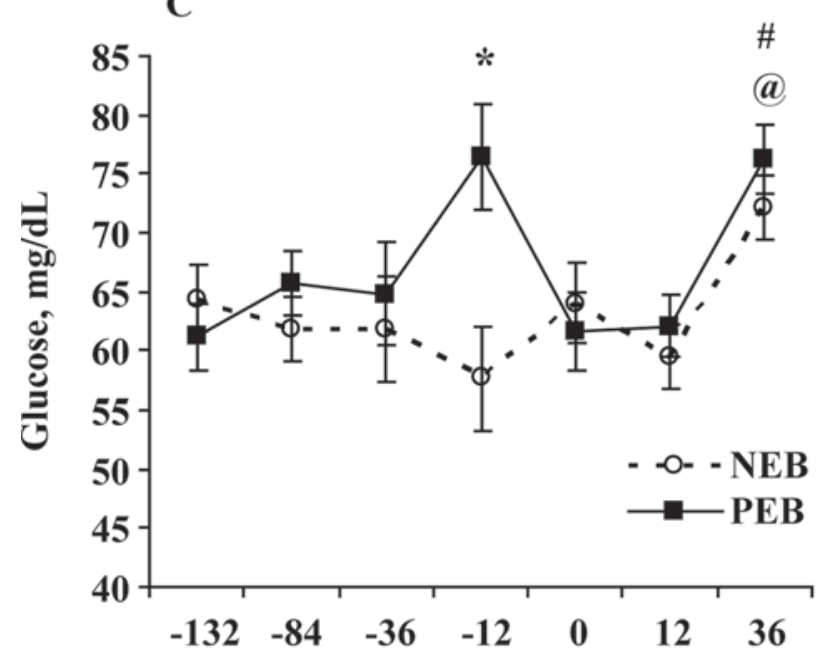

$\mathbf{E}$

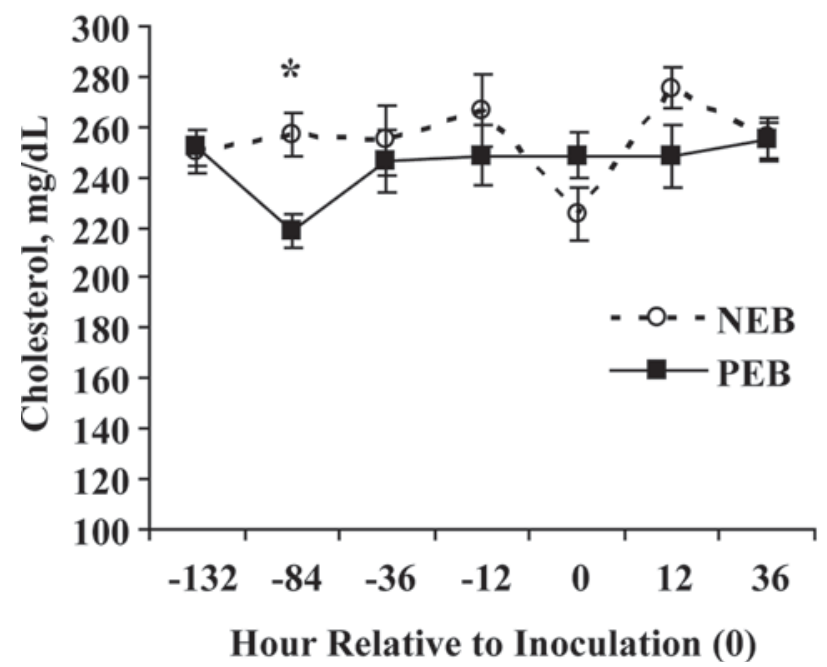

B

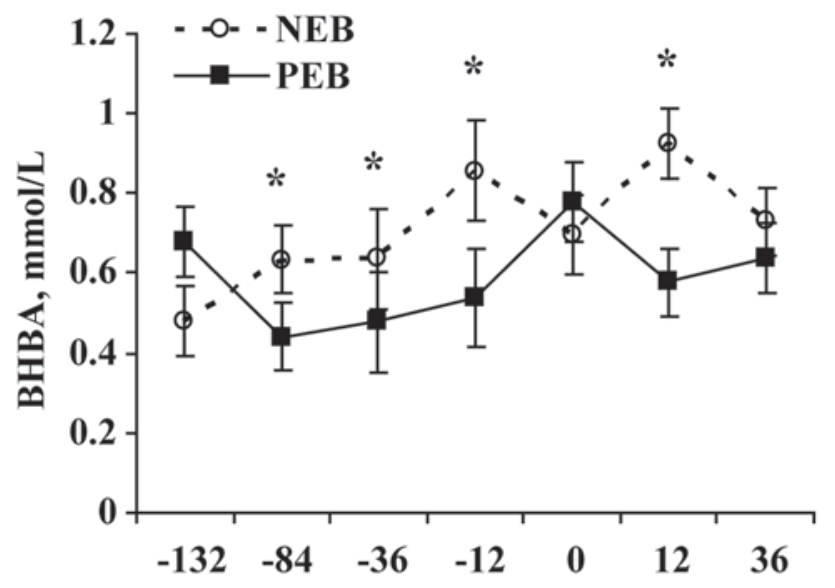

D
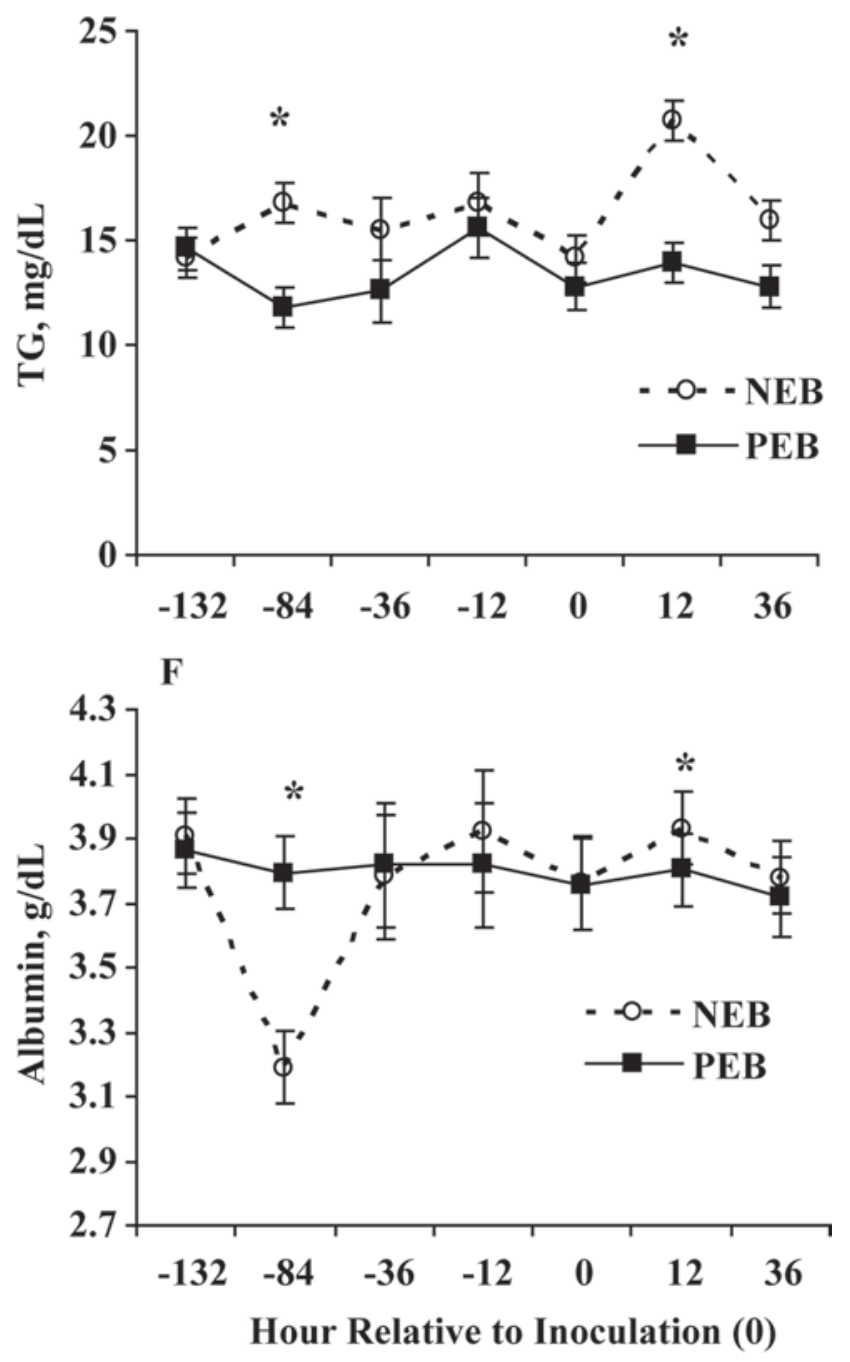

Figure 2. Serum concentrations of NEFA (A), BHBA (B), glucose (C), triglyceride (TG; D), cholesterol (E), and albumin (F) at time points relative to intramammary challenge with Streptococcus uberis $(\mathrm{h}=0)$ in 5 Holstein cows in dietary-induced negative energy balance $(\mathrm{NEB}$; $\bigcirc)$ and 5 Holstein cows in positive energy balance (PEB; $\mathbf{\square})$. All time points reflect samples collected from cows before the morning feeding, except for $0 \mathrm{~h}$, which was before the afternoon milking and after feed was offered. *Differences $(P<0.05)$ between NEB and PEB groups at a given time point. ${ }^{\#, @}$ Differences $(P<0.05)$ in serum glucose concentrations compared with $\mathrm{h}=0$ in NEB and PEB cows, respectively. 


\section{Clinical Indicators During Energy Balance and IMI Challenge}

During the RST period, heart rate (Supplemental Figure 2A; http://jds.fass.org/content/vol92/issue9/), and respiration rate (Supplemental Figure 2B) were lower ( $P<0.001$ and $P<0.001$, respectively) in NEB than in PEB cows. Although not significantly different between TRT during the RST period $(P=0.76)$, rectal temperature was lower $(P<0.001)$ in NEB than in PEB cows during the INF period. The imposed dietary energy deficiency, lower DMI (Figure 3A; $P<0.001$ ), and lower milk yield in NEB cows likely explain the lower heart rate and respiration rate during both the RST and INF periods.

Local signs of mastitis, such as flakes in the mammary secretion and a watery or yellow-colored mammary secretion, were observed after inoculation. Redness and hardening of the infected quarters was also observed after IMI challenge. Milk SCC from challenged quarters (Supplemental Figure 3A; http://jds.fass.org/content/ vol92/issue9/) was increased $(P<0.001 ; 5.41 \pm 0.17$ $\log _{10}$ cells $/ \mathrm{mL}$ ) by $20 \mathrm{~h}$ postinoculation compared with 0 and $12 \mathrm{~h}$ postinoculation regardless of TRT group, in agreement with the results of Smits et al. (1998). No differences (TRT $P=0.26$; TRT $\times$ hour $P=0.94$ ) in quarter milk SCC were observed between NEB and PEB cows after IMI challenge (Supplemental Figure 3B). In addition, no TRT differences were observed for colony-forming units per milliliter of Strep. uberis (Supplemental Figure 3C; $P=0.46$ ), but the interaction of TRT $\times$ hour (i.e., 0 h vs. $12,20,24,30$, and 36 h) was significant $(P<0.05)$. Shedding of Strep. uberis at any given time point was not different between TRT groups. By $12 \mathrm{~h}$ postinoculation, Strep. uberis was recovered from all challenged quarters and shedding continued through $36 \mathrm{~h}$ postinoculation similar to the results of others (Bannerman et al., 2004; Hoeben et al., 1999).

\section{Acute-Phase Proteins}

Serum. Serum concentrations of SAA and Hp at time points relative to IMI challenge $(0 \mathrm{~h})$ in NEB and PEB cows are shown in Figures $5 \mathrm{~A}$ and $5 \mathrm{~B}$, respectively. During the RST period, SAA was lower $(P=$ $0.05)$ for NEB cows than for PEB cows $(10.2 \pm 4.2$ and $17.4 \pm 3.9 \eta \mathrm{g} / \mathrm{mL}$, respectively) primarily because of responses at $0 \mathrm{~h}$, which also led to a significant $(P=$ $0.05)$ TRT $\times$ hour interaction. No difference in serum Hp concentration was observed between TRT during the RST period. During the INF period, hour relative to IMI challenge and the TRT $\times$ hour interaction were highly significant for both SAA $(P<0.001)$ and $\mathrm{Hp}(P$
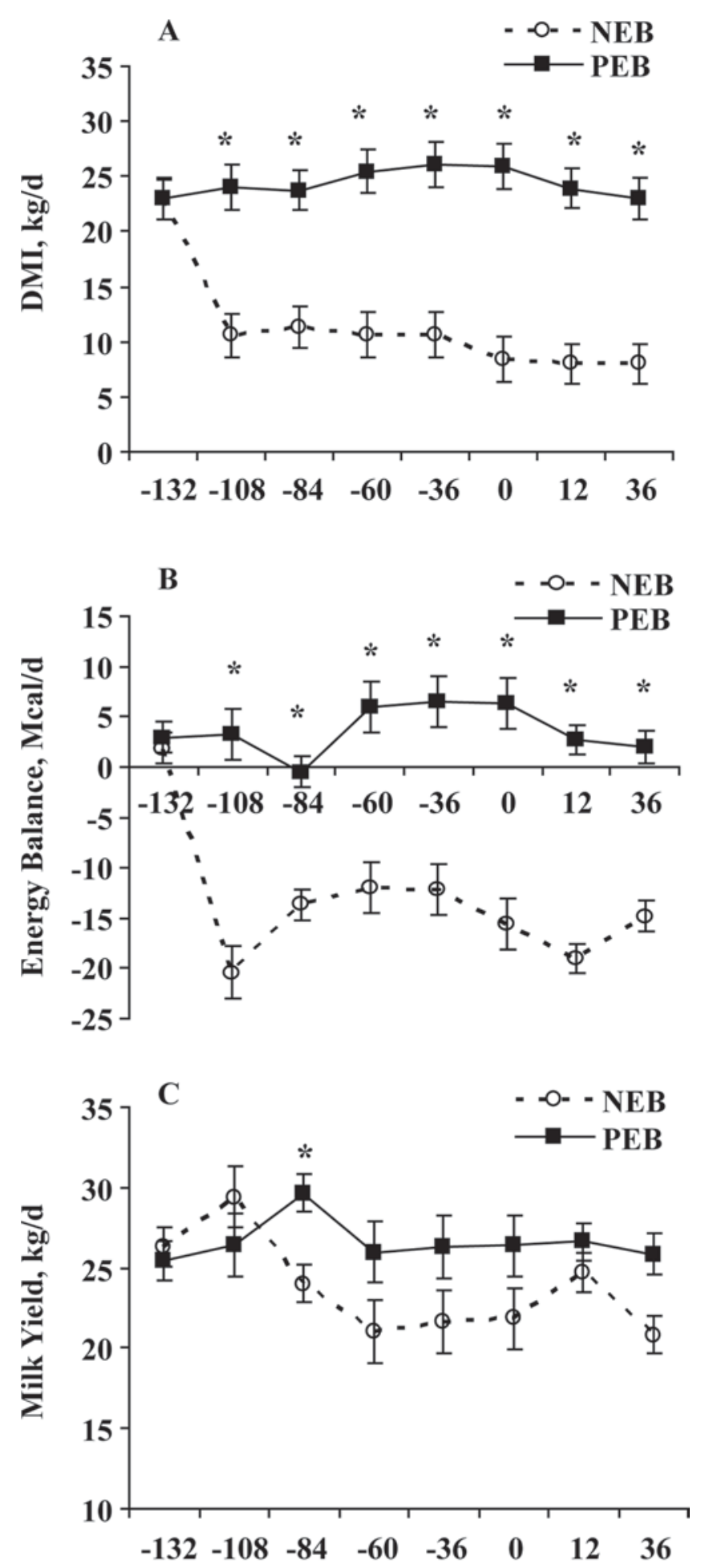

Hour Relative to Inoculation (0)

Figure 3. Daily DMI (A), energy balance (B), and milk yield (C) in 5 Holstein cows in dietary-induced negative energy balance (NEB; O) and 5 Holstein cows in positive energy balance (PEB; $\mathbf{\square})$. Time points are relative to intramammary challenge with Streptococcus uberis $(\mathrm{h}=0)$. *Differences $(P<0.05)$ between NEB and PEB groups at a given time point. 
$<0.001)$. Both SAA and Hp increased after inoculation regardless of TRT. The concentration of SAA did not differ between TRT at any given time point. Thirtysix hours after IMI challenge, serum Hp concentration was higher $(P<0.001)$ in NEB $(0.51 \pm 0.03 \mathrm{mg} / \mathrm{mL})$ than in PEB cows $(0.42 \pm 0.03 \mathrm{mg} / \mathrm{mL})$. The NEB cows had higher SAA concentrations at 20,30, and 36 $\mathrm{h}$ after IMI challenge when compared with $0 \mathrm{~h}$, and PEB cows had higher SAA concentrations at 30 and 36

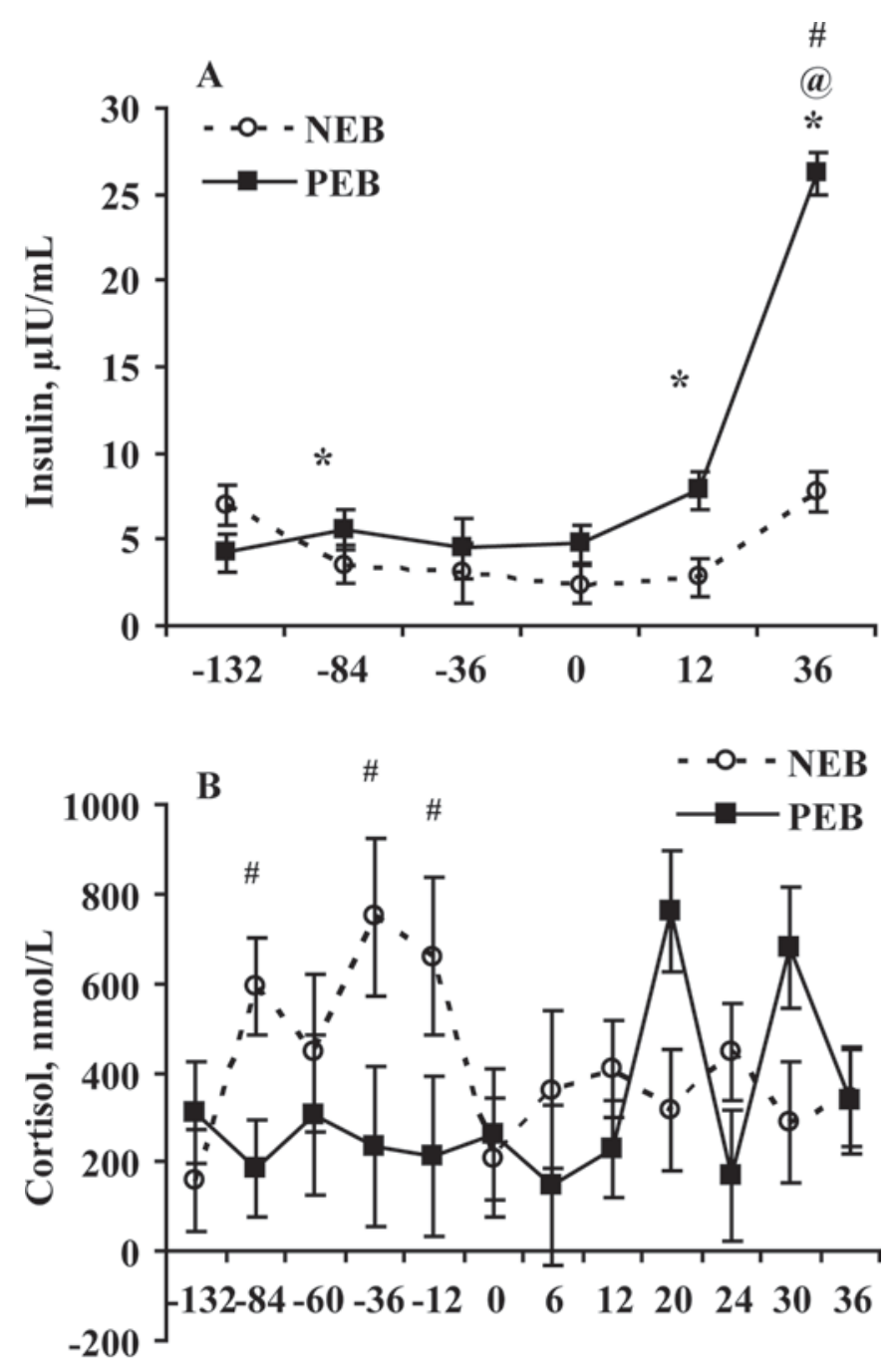

\section{Hour Relative to Inoculation (0)}

Figure 4. ${ }^{*}$ Differences $(P<0.05)$ in serum insulin $(\mathrm{A})$ and cortisol (B) concentrations between 5 Holstein cows in dietary-induced negative energy balance (NEB; $\mathrm{O}$ ) and 5 Holstein cows in positive energy balance (PEB; $\mathbf{D})$. Time points are relative to intramammary challenge with Streptococcus uberis $(\mathrm{h}=0)$. For insulin only, samples were collected before the morning feeding. For insulin, ${ }^{\#, @}$ differences $(P<0.05)$ in serum insulin concentrations compared with $\mathrm{h}=0$ in NEB and PEB cows, respectively. For cortisol, ${ }^{\#}$ differences $(P<0.05)$ in serum cortisol concentrations compared with $\mathrm{h}=-132$ (i.e., before feed restriction) in NEB cows. h compared with 0 h. Both NEB and PEB cows had higher $(P<0.05)$ serum Hp at 6,30 , and $36 \mathrm{~h}$. At $36 \mathrm{~h}$ post-IMI, cows in NEB had higher $(P<0.05)$ Hp than cows in PEB.

Milk. The effect of IMI challenge on milk SAA and milk $\mathrm{Hp}$ concentrations are shown in Figure 5C and Figure 5E, respectively. Milk SAA concentration increased $(P<0.05)$ from 0 to $20 \mathrm{~h}$ after IMI challenge. In contrast, a decrease $(P<0.05)$ in milk Hp concentration was observed at $20 \mathrm{~h}$ when compared with $0 \mathrm{~h}$. Milk SAA concentration was higher (Figure 5D; $P<$ $0.05)$ in NEB $(6.6 \pm 1.7 \eta \mathrm{g} / \mathrm{mL})$ than in PEB cows $(1.6$ $\pm 1.6 \eta \mathrm{g} / \mathrm{mL}$ ) primarily because of differences at $20-\mathrm{h}$ post-IMI; however, the TRT $\times$ hour interaction was not significant $(P=0.13)$. No TRT differences $(P=$ 0.44 ) were observed in milk Hp concentrations (Figure $5 \mathrm{~F})$, but the TRT $\times$ hour interaction was significant $(P$ $<0.05$ ). Differences between NEB and PEB cows were not significant at any given time point. Within PEB cows, milk Hp concentrations were lower at 12 and 20 $\mathrm{h}$ when compared with $0 \mathrm{~h}$ of IMI challenge; however, no significant changes in milk $\mathrm{Hp}$ were detected in NEB cows.

\section{PMNL Chemotaxis and Phagocytosis}

Figure 6A shows the effect of IMI challenge with Strep. uberis on PMNL migration (i.e., chemotaxis) in response to chemoattractants IL-8 and C5a. During the RST period, there were no differences in PMNL chemotactic responses between chemoattractants $(P=$ 0.29). For both IL-8 and complement C5a, an overall decrease in neutrophil migration was observed at -84 h (i.e., $48 \mathrm{~h}$ after feed restriction; $P<0.001$ ) when compared with $-132 \mathrm{~h}$ (i.e., before feed restriction) and $0 \mathrm{~h}$ relative to IMI challenge. During the INF period, PMNL migration was greater $(P<0.05)$ when assessed with IL-8 $\left(2.15 \pm 0.10 \log _{10}\right.$ cells migrating $)$ than C5a $\left(2.01 \pm 0.10 \log _{10}\right.$ cells migrating). For C5a, PMNL chemotaxis was decreased (chemoattractant $\times$ hour, $P$ $<0.01$ ) at $36 \mathrm{~h}$ when compared with $0 \mathrm{~h}$ relative to IMI challenge. There were no effects of TRT or TRT $\times$ hour interaction on PMNL chemotaxis in response to either chemoattractant during the INF or RST period (Figure 6B).

An inverse response was observed between the RST and INF periods for PMNL phagocytosis (Figure 7A). The PMNL phagocytosis was greater $(P<0.01)$ at -132 and $-84 \mathrm{~h}$ but lower $(P<0.01)$ at 24 and $36 \mathrm{~h}$ when compared with $0 \mathrm{~h}$ relative to IMI challenge. At 0 h, PMNL phagocytosis was lower (Figure 7B; $P<0.05$ ) in NEB cows $(31.5 \pm 0.6 \%)$ than in PEB cows $(33.2$ $\pm 0.7 \%)$. No differences between TRT were observed at any other time points. Within TRT, both NEB and 

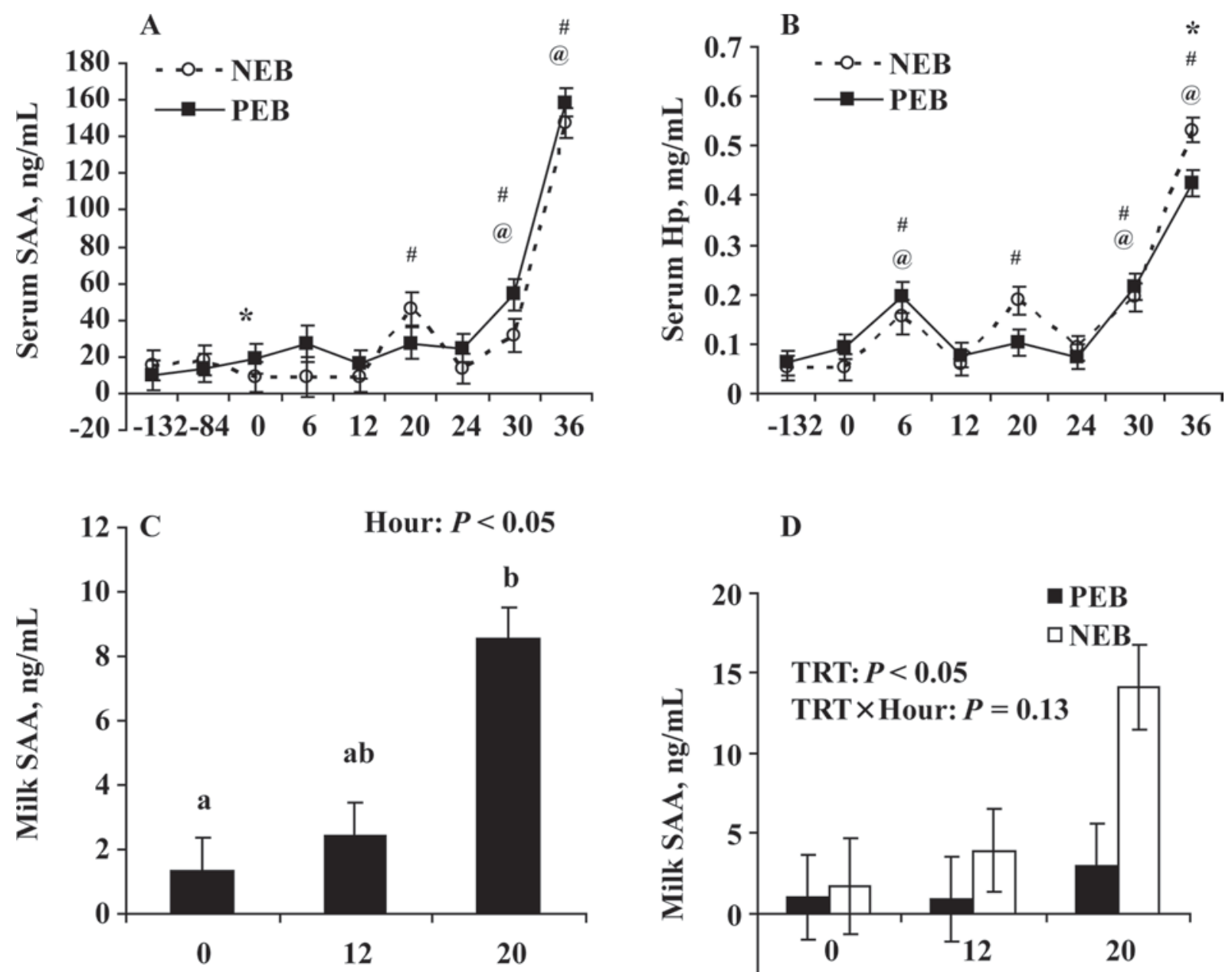

D
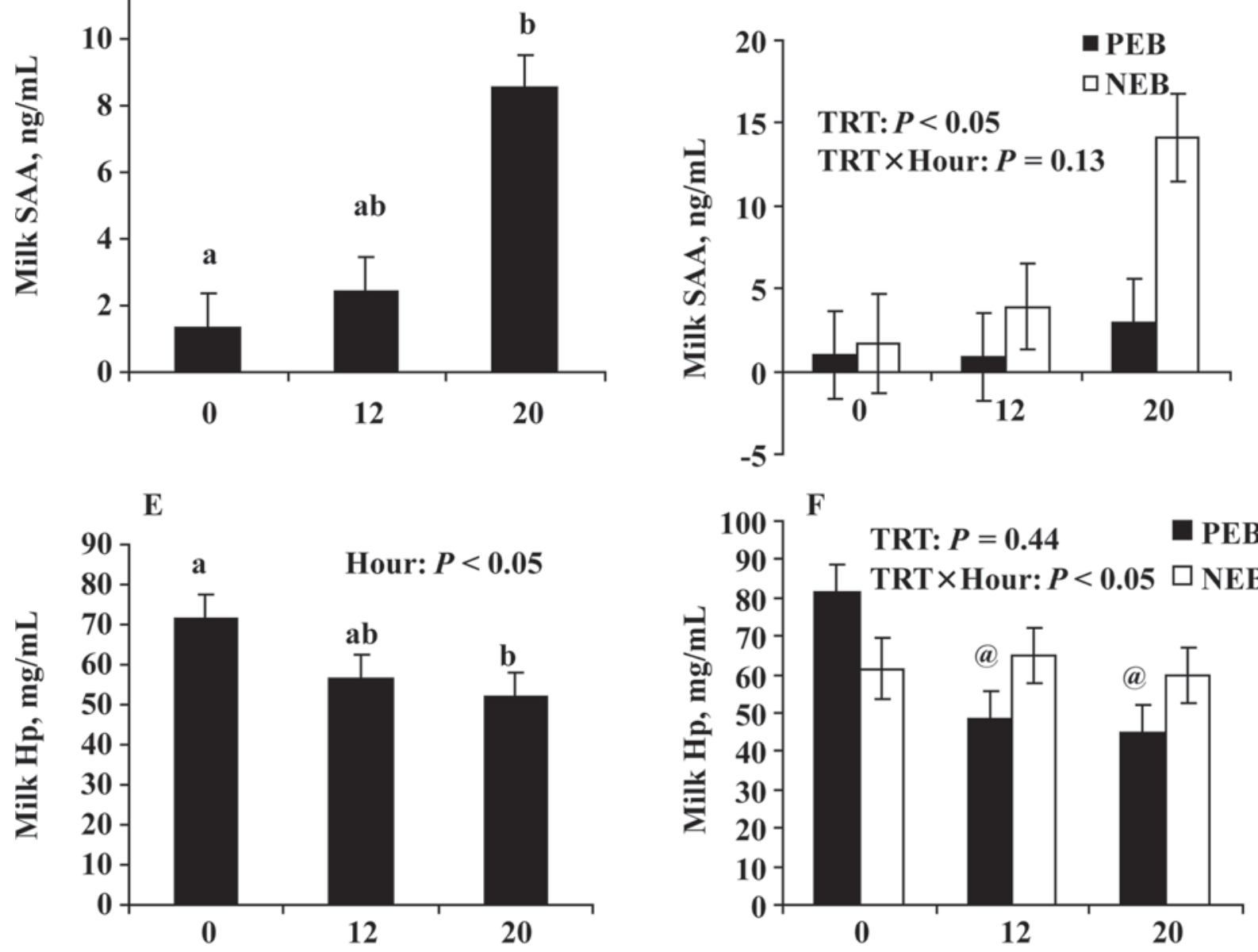

Hour Relative to Inoculation (0)

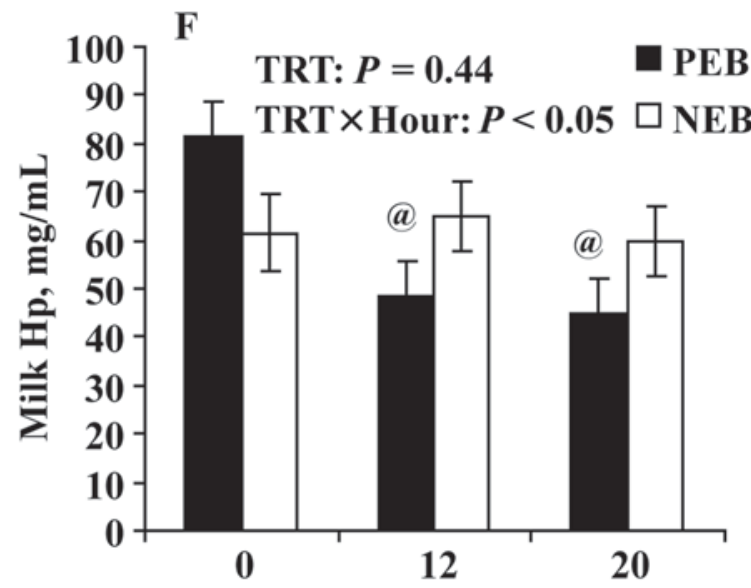

Hour Relative to Inoculation (0)

Figure 5. Concentrations of serum amyloid A (SAA; A) and serum haptoglobin (Hp; B) concentrations in 5 Holstein cows in dietary-induced negative energy balance (NEB; $O$ ) and 5 Holstein cows in positive energy balance (PEB; $\mathbf{0})$. Time points are relative to intramammary challenge with Streptococcus uberis $(\mathrm{h}=0)$. Milk SAA $(\mathrm{C})$ and $\mathrm{Hp}(\mathrm{E})$ after intramammary challenge with Streptococcus uberis in 10 Holstein cows, regardless of dietary treatment (TRT). Differences between NEB (open bars; $\square$ ) and PEB (solid bars; $\mathbf{\square}$ ) cows on milk SAA (D) and $\mathrm{Hp}(\mathrm{F})$ concentrations after intramammary challenge. For milk, no TRT differences $(P>0.10)$ were observed at any given time point. ${ }^{\mathrm{a}, \mathrm{b}}$ Least squares means $( \pm$ SEM $)$ with differing letters differ $(P<0.05)$. ${ }^{*}$ Differences $(P<0.05)$ between NEB and PEB groups at a given time point. ${ }^{\#, @}$ Differences $(P<0.05)$ compared with $\mathrm{h}=0$ in NEB and PEB cows, respectively. 
A

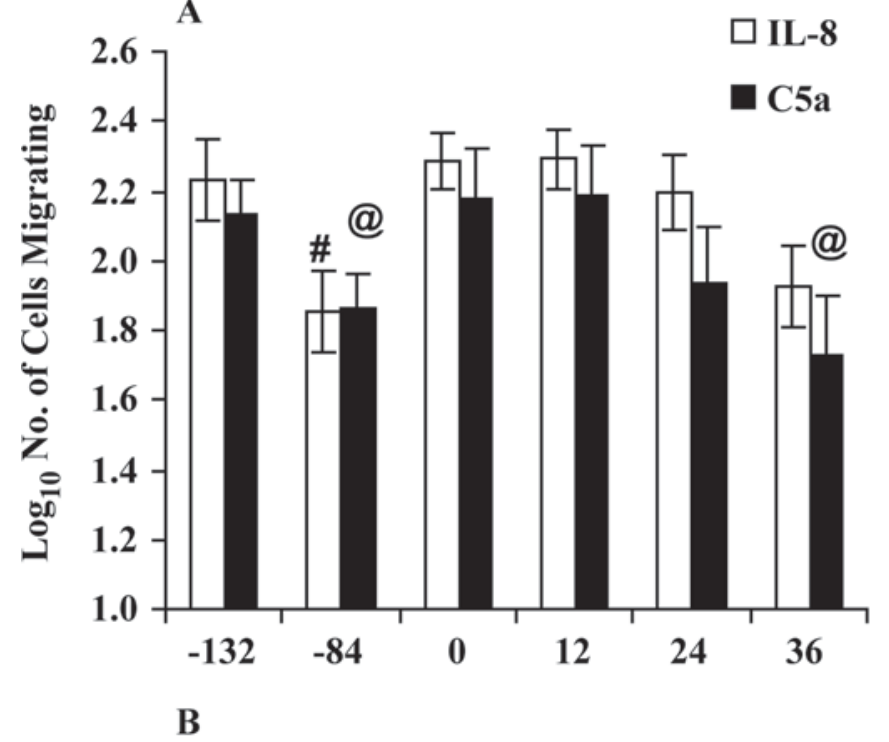

$\square$ NEB C5a $\square$ PEB C5a $\square$ NEB IL-8 $\square$ PEB IL-8

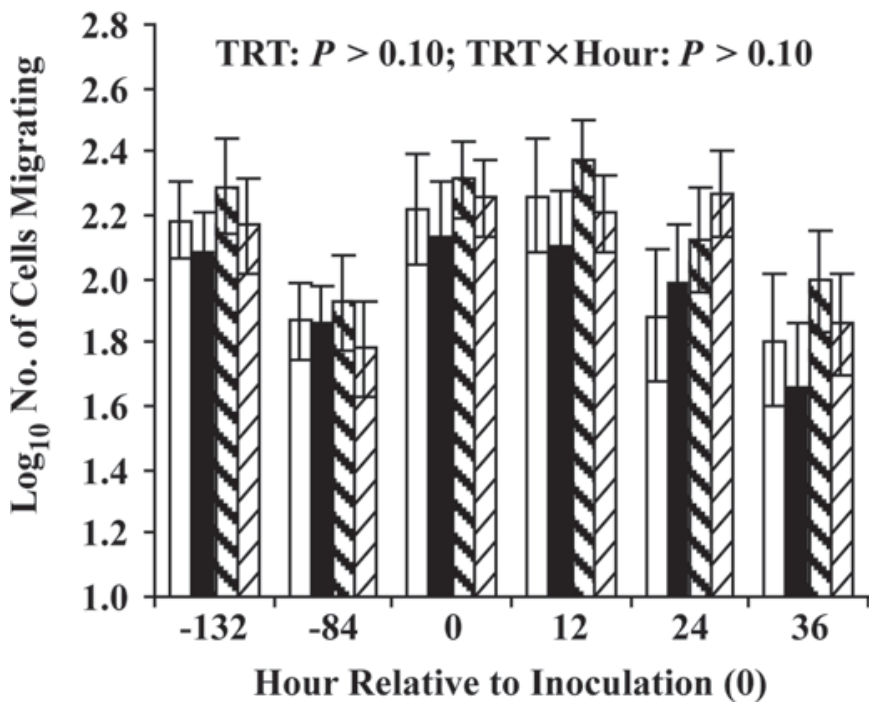

Figure 6. The effect of intramammary challenge with Streptococcus uberis on the blood neutrophil chemotactic response to IL-8 (open bars; $\square$ ) and complement component C5a (solid bars $\mathbf{\square}$; A) in 10 Holstein cows. Time points are relative to intramammary challenge $(\mathrm{h}=0) .{ }^{\#, @}$ Differences $(P<0.05)$ in number of cells migrating with regard to IL- 8 and C5a, respectively, compared with either $\mathrm{h}=-132 \mathrm{~h}$ or $\mathrm{h}=0$. The effect of treatment [TRT; i.e., 5 Holstein cows in either dietary-induced negative energy balance (NEB) or positive energy balance (PEB)] on neutrophil chemotaxis (B). No TRT differences $(P<$ 0.05 ) were observed at any given time point. Values represent the average number of neutrophils that migrated in response to the specific chemoattractant, averaged over 5 fields per well.

PEB cows had lower PMNL phagocytosis $(P<0.001)$ at 24 and $36 \mathrm{~h}$ compared with the respective groups at $0 \mathrm{~h}$ after IMI challenge.

No differences were observed for the percentage of mature PMNL during the RST period, where mature PMNL represented the majority $(92.1 \pm 2.3 \%)$ of the

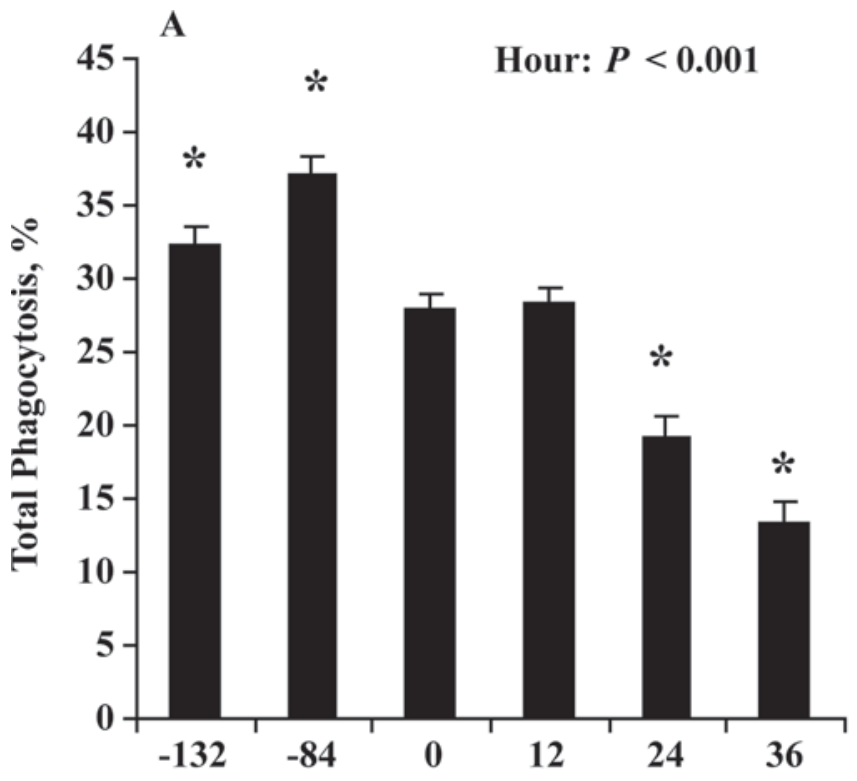

B

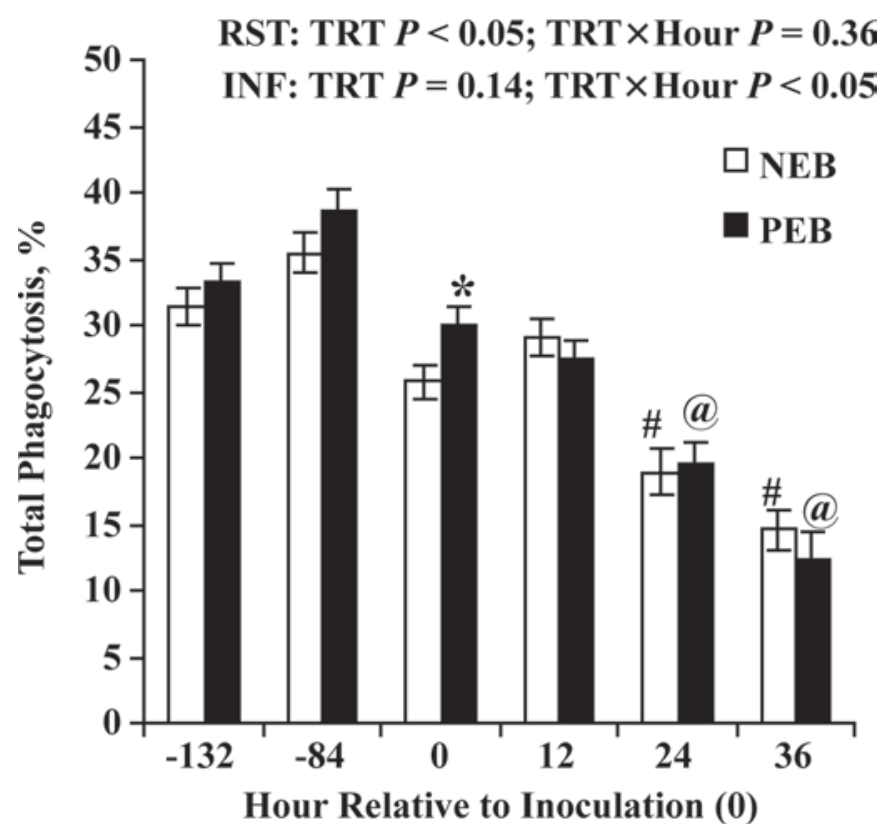

Figure 7. ${ }^{*}$ Differences $(P<0.05)$ in the percentage of engulfment of fluorescent beads (A) by bovine blood neutrophils as a measure of phagocytosis at time points relative to intramammary challenge with Streptococcus uberis $(\mathrm{h}=0)$ in 10 Holstein cows. The effect of treatment [TRT; i.e., either 5 Holstein cows in dietary-induced negative energy balance (NEB; open bars; $\square$ ) or positive energy balance (PEB; solid bars; $\square)$ on neutrophil phagocytosis $(\mathrm{B}) .{ }^{*}$ Differences $(P<0.05)$ between NEB and PEB cows at a given time point. ${ }^{\#,}$ Differences $(P$ $<0.05)$ in neutrophil phagocytosis compared with $\mathrm{h}=0$ in NEB and $\mathrm{PEB}$ groups, respectively. RST $=$ feed restriction period prechallenge; $\mathrm{INF}=$ infection period postchallenge. 
total PMNL population in blood (Supplemental Figure 4A; http://jds.fass.org/content/vol92/issue9/). The overall decrease in both PMNL phagocytic and chemotactic responses after IMI challenge may be partially explained by the $27 \%$ decrease $(P<0.001)$ in the percentage of mature PMNL at $24 \mathrm{~h}$ after IMI challenge $(66.7 \pm 3.0 \%)$ compared with $0 \mathrm{~h}(93.8 \pm 3.0 \%)$. No differences attributable to TRT were observed during the RST or INF periods (Supplemental Figure 4B; $P$ $=0.70)$. Within NEB cows, PMNL maturity decreased by $12 \mathrm{~h}(P<0.05)$, followed by a further decrease at $24 \mathrm{~h}(P<0.001)$ postinoculation. Within PEB cows, a decrease in PMNL maturity was not observed until 24 $\mathrm{h}(P<0.001)$ postinoculation.

\section{Proinflammatory Cytokines and Oxidative Stress Proteins in Milk}

Supplemental Figure 5 (http://jds.fass.org/content/ vol92/issue9/) shows the effect of IMI challenge on milk IL-10 (Supplemental Figure 5A), TNF- $\alpha$ (Supplemental Figure 5C), and IL-1 $\beta$ (Supplemental Figure $5 \mathrm{E})$ concentrations. Twenty hours after IMI challenge, concentrations of these cytokines were not statistically different $(P=0.85,0.44$, and 0.14 , respectively) from prechallenge concentrations $(0 \mathrm{~h})$. A mammary biopsy was performed $20 \mathrm{~h}$ after IMI challenge on both rear quarters of all cows; therefore, whey was not isolated from milk samples thereafter because of changes in milk composition (e.g., blood clots). No TRT effects or TRT $\times$ hour interactions $(P>0.60)$ were observed for milk IL-10 (Supplemental Figure 5B), TNF- $\alpha$ (Supplemental Figure 5D), and IL-1 $\beta$ concentrations (Supplemental Figure 5F). Milk SOD activity decreased $(P<0.01)$ after IMI challenge (Supplemental Figure 6A; http:// jds.fass.org/content/vol92/issue9/), but milk GPX activity was unchanged (Supplemental Figure 6C). The effects of TRT and the TRT $\times$ hour interaction were not significant for milk SOD (Supplemental Figure 6B) or GPX (Supplemental Figure 6D).

\section{DISCUSSION}

\section{Metabolic Indicators}

Restricting dietary energy intake to $60 \%$ of $\mathrm{NE}_{\mathrm{L}}$ requirements in midlactation Holstein cows resulted in a calculated NEB similar to that observed during the periparturient period (e.g., Rastani et al., 2001) and allowed us to investigate the effects of NEB on immune function and the innate immune response to Strep. uberis IMI challenge. The feed-restricted cows had increased serum NEFA and BHBA concentrations and lower calculated energy balance when compared with PEB cows during both the RST and INF periods. However, serum glucose concentrations were not different between TRT groups during both the RST and INF periods. Mean serum glucose concentrations for NEB cows during the RST period $(61.6 \mathrm{mg} / \mathrm{dL})$ were greater than those observed in cows during the first 1 to 10 DIM in previous studies from our laboratories (e.g., $51.1 \mathrm{mg} / \mathrm{dL}$; Dann et al., 2006). Although the energy required to elicit an immune response in cattle remains unknown, glucose is essential for proliferation, survival, and differentiation of phagocytic cells (PMNL and macrophages) and has been shown to be the preferred metabolic fuel rather than fatty acids, AA, or ketone bodies during inflammation for activated PMNL, macrophages, and lymphocytes (Pithon-Curi et al., 2004). The lack of marked differences in serum glucose concentrations between TRT groups, combined with the fact that the mean serum glucose concentrations in NEB cows were greater than those of cows experiencing postpartal NEB (Dann et al., 2006), may partly explain the minimal alterations in immune function observed between NEB and PEB cows in this study.

Serum insulin and glucose concentrations increased in both TRT groups after Strep. uberis IMI challenge, with a more pronounced increase in insulin concentration in PEB cows by $36 \mathrm{~h}$ postinoculation. Other researchers have observed elevated plasma insulin and glucose concentrations after $E$. coli LPS infusion (Waldron et al., 2006). Those researchers attributed the increased circulating glucose concentrations to enhanced glycogenolysis and gluconeogenesis; hyperglycemia in turn led to increased insulin secretion. To our knowledge, the metabolism and fates of energetic fuels in bovine leukocytes have not been examined. Although BHBA and NEFA have been shown to impair immune cell function in vitro (Calder et al., 1990; Hoeben et al., 1997; Suriyasathaporn et al., 1999), further research examining the role of glucose as a primary, if not the only, fuel used by bovine leukocytes may help explain the increased serum glucose and insulin concentrations observed during an IMI challenge. Furthermore, because serum glucose concentrations are lowest in cows during early lactation (Guo et al., 2007), low glucose availability might limit immune system function; glucose availability thus may provide a mechanistic link between postpartal NEB and risk of Strep. uberis-associated mastitis in dairy cows.

\section{Serum Cortisol and Energy Balance}

The changing steroid environment (cortisol, progesterone, and estradiol) associated with gestation, parturition, and the onset of lactation has been shown to be a major factor contributing to impairment of the immune system during the periparturient period (Cai 
et al., 1994). Numerous studies have demonstrated impaired chemotaxic and phagocytic capabilities of PMNL around parturition when compared with mid- to late lactation (Mehrzad et al., 2001). During both the RST and INF periods, serum cortisol concentrations were not different $(P>0.05)$ between TRT groups because of large biological variation and the relatively low number of animals. These data indicate that serum cortisol concentrations likely had minimal effects on immune responses during midlactation.

\section{Cytokines and Acute-Phase Proteins}

Serum albumin was sharply decreased in NEB cows relative to PEB cows at $-84 \mathrm{~h}$ relative to Strep. uberis IMI challenge (i.e., $48 \mathrm{~h}$ of feed restriction). Blood albumin is considered a negative acute-phase protein and a positive indicator of liver function early postpartum (Bertoni et al., 2008). During a state of postpartal NEB, rapid tissue energy mobilization occurs, potentially leading to depletion of liver-derived albumin, a carrier protein for NEFA in circulation. Thus, serum albumin and NEFA are negatively related (Seifi et al., 2007). By $0 \mathrm{~h}$ relative to inoculation, serum albumin in NEB cows was equivalent to that of PEB cows, indicating repletion of albumin via endogenous albumin synthesis in the liver. Greater NEFA in NEB cows post-IMI indicated that tissue energy mobilization was still occurring, which may explain the elevated serum albumin concentrations observed by $12 \mathrm{~h}$. This finding is opposite the results of Van Merris et al. (2004), in which serum albumin was lower through the first day post-IMI challenge. However, Van Merris et al. (2004) reported that albumin concentrations essentially returned to pre-IMI levels as early as $2 \mathrm{~d}$ post-IMI, which agrees with our findings at $36 \mathrm{~h}$ postinfection.

Members of the SAA family and $\mathrm{Hp}$, an $\alpha_{2}$-globulin, are primarily synthesized and secreted from the liver but mammary synthesis during mastitis has been reported (Petersen et al., 2004; Suojala et al., 2008). Serum SAA concentrations were moderately lower in NEB than in PEB cows during the $132 \mathrm{~h}$ of feed restriction. These results contradict the positive associations observed among serum concentrations of SAA, NEFA, and hepatic lipidosis (i.e., fatty liver syndrome) in dairy cows during the periparturient period (Ametaj et al., 2005). The increase in milk SAA in NEB versus PEB during the INF period supports the results of Ametaj et al. (2005). Serum amyloid A has been shown to be associated with high-density lipoproteins (Baumberger et al., 1991) and proinflammatory cytokines such as TNF- $\alpha$, IL-6, and IL-1 (Ametaj et al., 2005). Circulating concentrations of TNF- $\alpha$, IL-6, and IL-1 were not measured in our study. Previous studies with humans (Salas-Salvadó et al., 2006) suggest that energy deficiency per se is associated with a decrease in blood SAA concentrations during weight loss. It is likely that the liver of cows in NEB decreased rates of protein synthesis, thus partly accounting for lower serum SAA. The reason for lower serum SAA observed in dietary-induced NEB versus $\mathrm{PEB}$ cows in midlactation is unclear and may indicate that increased circulating glucocorticoid concentrations and other unknown biological factors may contribute to the positive associations between serum SAA and hepatic lipidosis in dairy cows during the periparturient period.

As expected, serum and milk SAA concentrations during Strep. uberis IMI challenge were higher than preinoculation concentrations regardless of dietary treatment, with dramatic increases in serum observed by $36 \mathrm{~h}$ postinoculation. Similar results supporting the proinflammatory role of SAA have been reported in milk and serum after IMI challenge with Strep. aureus (Grönlund et al., 2003) and Strep. uberis (Petersen et al., 2003). Researchers have reported that the main source of milk SAA during mastitis is mammary epithelial cells (Wellnitz and Kerr, 2004). Mammary quantitative PCR results from our study (data not shown) revealed a 64.7 -fold increase in expression of $S A A 1$ in mammary tissue from infected versus noninfected quarters, regardless of TRT.

The primary biological functions of $\mathrm{Hp}$, a positive acute-phase protein, involve binding to hemoglobin, stimulating angiogenesis, and inhibiting respiratory burst activity of PMNL (Oh et al., 1990). Studies have indicated an association between increased serum Hp concentration and hepatic lipidosis in periparturient dairy cows (Ametaj et al., 2005). Furthermore, greater blood Hp has been observed in early postpartum cows exhibiting increased inflammatory conditions (Bionaz et al., 2007). In the current study, both TRT groups had elevated serum Hp concentrations during the INF period, with NEB cows having higher concentrations than PEB cows at $36 \mathrm{~h}$ postchallenge. This response is in line with previous observations from Bionaz et al. (2007) and emphasizes a link between NEB and immune response as indicated by altered hepatic Hp secretion during postpartal NEB. Greater liver Hp production may be a biological response of the animal to fight invading pathogens.

In contrast with serum, milk $\mathrm{Hp}$ concentrations decreased during the INF period primarily because of a decline in PEB cows. This finding contradicts other studies that indicated positive relationships between serum and milk concentrations of Hp during an IMI challenge in cows that were in PEB (Grönlund et al., 2003). Possibly, circulating Hp was not being actively taken up by the mammary gland, but rather was being 
used by other tissues or cleared from the animal via feces or urine. At $20 \mathrm{~h}$ after IMI challenge and before peak clinical signs of disease, a mammary biopsy was performed on both rear quarters of all cows; thus, we did not measure Hp in milk at that time. It seems likely that increased amounts of $\mathrm{Hp}$ were transported into the mammary gland as result of mammary biopsies.

Of the acute-phase proteins, SAA is considered a "first responder" and concentrations in serum and milk have been shown to increase as early as $4 \mathrm{~h}$ postinoculation (Petersen et al., 2004), which was observed in the present study. In contrast, $\mathrm{Hp}$ is considered a "secondary responder," with a slower increase in serum and milk concentrations during infection (Petersen et al., 2004). Therefore, measurement of milk Hp concentration during peak clinical signs of mastitis $(>20 \mathrm{~h}$ postinoculation) might have revealed elevated concentrations. Increased concentrations of blood and milk SAA and Hp are stimulated by cytokines such as IL1 $\beta$, IL-6, and TNF- $\alpha$ (Petersen et al., 2004). Despite numerical increases through $20 \mathrm{~h}$ post-IMI challenge, no statistical differences in milk IL-1 $\beta$ or TNF- $\alpha$ were observed in our study, which suggests that changes in milk and serum SAA and Hp concentrations were not affected by local cytokine production, but rather by circulating cytokine concentrations (not measured) or other biological factors. Further studies involving the effect of NEB and hepatic lipidosis on milk $\mathrm{Hp}$ and SAA concentrations during an IMI are warranted.

\section{Oxidative Stress Response in Mammary Gland}

The innate immune response is the first line of defense against invading organisms and is directly related to acute and chronic inflammation of the mammary gland. Milk macrophages are phagocytic cells that are the first cells, besides mammary epithelial cells, to encounter invading organisms. Macrophages have the ability to release proinflammatory cytokines such as IL-1 $\beta$ and TNF- $\alpha$, which stimulate PMNL recruitment (Rainard and Riollet, 2006). However, prolonged inflammation can cause damage to host cells via increased cytokine concentrations and the generation of reactive oxygen metabolites during phagocytosis. Host cells have several enzymes, including SOD and GPX, that have antioxidant capabilities and that reduce reactive oxygen species to less reactive metabolites. Acute-phase proteins and the secretion of antiinflammatory mediators (e.g., IL-10) via macrophages, T-helper 2 cells, and B cells help to restore homeostasis and minimize mammary tissue damage during the inflammatory response (Rainard and Riollet, 2006).

Although no statistical differences in milk SOD or GPX activity were observed because of NEB in our study, Hoeben et al. (1997) reported previously that respiratory burst activity of leukocytes in culture media supplemented with high concentrations (1 and $2.5 \mathrm{mM}$ ) of BHBA were 10 and $15 \%$ lower, respectively, when compared with the respiratory burst activity of culture media supplemented with 0.01, 0.05, or $0.1 \mathrm{~m} M$ BHBA. Cytokine concentrations in milk remained unchanged by $20 \mathrm{~h}$ postinoculation and no differences attributable to energy balance were observed relative to IMI challenge with Strep. uberis. Unfortunately, whey could not be isolated from milk after $20 \mathrm{~h}$ post-IMI challenge because of side effects of mammary biopsies. Bannerman et al. (2004) challenged lactating Holstein cows with $220 \mathrm{cfu}$ of Strep. uberis (strain O140J) and did not observe elevated concentrations of IL- $1 \beta$, TNF- $\alpha$, and IL-10 until approximately $30 \mathrm{~h}$ postchallenge, which could explain the minimal responses observed in our study.

\section{PMNL Function}

Neutrophils are the major cell type observed in mammary secretions during inflammation; therefore, the ability of PMNL to migrate to the site of infection (i.e., chemotaxis) and engulf invading pathogens is critical to the efficiency of the innate immune response (Rainard and Riollet, 2006). There was no effect of NEB on PMNL chemotaxis in vitro in this study; thus, our results seem to contradict those of Suriyasathaporn et al. (1999). However, average serum BHBA concentrations of NEB cows $(0.70 \mathrm{~m} M)$ were similar to cows experiencing postpartal NEB but were not as high as those seen during subclinical ketosis (Walsh et al., 2007). In contrast, Suriyasathaporn et al. (1999) supplemented culture media with BHBA to achieve concentrations normally observed in periparturient cows with clinical or subclinical ketosis $(1.6 \mathrm{mM})$. They observed a reduced chemotactic differential $(2.1 \mathrm{mM})$ when compared with control culture $(5.7 \mathrm{~m} M)$ media not supplemented with BHBA. Suriyasathaporn et al. (1999) hypothesized that chemotaxis decreased in serum containing high concentrations of BHBA because leukocyte migration is glucose dependent (Kluciński et al., 1988) and the cells could not use ketones as a supplemental energy source. In our study, serum glucose concentrations were not significantly different between NEB and PEB cows during the RST and INF periods, which may partially explain the lack of effects observed in PMNL chemotactic responses despite the greater serum BHBA concentrations in NEB cows throughout the study period. Whether BHBA itself interferes with PMNL chemotaxis remains uncertain. It is important to note that for our study, functional measurements of PMNL required removal from an environment contain- 
ing serum NEFA and BHBA concentrations in NEB cows that were similar to those found to alter immune cell function (Hoeben et al., 1997; Suriyasathaporn et al., 1999); therefore, the negative effects of BHBA and NEFA on PMNL chemotaxis in vitro may largely have been eliminated.

Overall, NEB cows had a lower percentage of PMNL phagocytosis in vitro than PEB cows. Glucose is the primary, if not the only, fuel source used by PMNL and macrophages for phagocytosis (Pithon-Curi et al., 2004). The energy requirements of bovine PMNL for phagocytic and chemotactic functions are unclear, but our results indicate that phagocytic function may be more affected than chemotaxis in cows experiencing dietary-induced NEB compared with cows in PEB. Although serum glucose was not different between NEB and PEB cows, serum NEFA and BHBA were higher in NEB than in PEB cows; in vitro studies have shown that NEFA and BHBA impair the phagocytic capability of immune cells through unknown mechanisms (Kluciński et al., 1988; Calder et al., 1990). Even though PMNL were removed from the circulating environment before in vitro phagocytosis measurements, the higher BHBA and NEFA observed in NEB cows may have contributed to lower PMNL phagocytic capabilities when compared with PEB cows.

\section{CONCLUSIONS}

Cows in midlactation restricted to $60 \%$ of $\mathrm{NE}_{\mathrm{L}}$ requirements for $7 \mathrm{~d}$ had a calculated NEB similar to those of cows experiencing postpartal NEB. The NEB cows had elevated NEFA and BHBA in blood, but BHBA concentrations were not reflective of cows experiencing subclinical or clinical ketosis during the periparturient period. In addition, minimal differences in serum glucose concentrations were observed when compared with PEB cows. The degree of metabolic challenge in our study is thus one factor that may explain the relative lack of effects of NEB on immune function during the Strep. uberis IMI challenge. Therefore, dietary-induced NEB models, regardless of severity and duration, do not seem to reflect studies that have observed negative correlations between energy balance, circulating metabolites, and increased susceptibility to IMI in dairy cows during postpartal NEB. Low glucose concentrations combined with the changing glucocorticoid environment, as well as other as yet unidentified factors in periparturient cows, are likely major factors that contribute to the impairment of the immune function during the transition period.

\section{ACKNOWLEDGMENTS}

Financial support for this project was provided in part by the USDA, Cooperative State Research, Education, and Extension Service, Section 1433 Animal Health and Disease Funds, appropriated to the Illinois Agricultural Experiment Station under project No. ILLU-538-981 and NRI competitive grant 2007-35204-17758 (both to Juan Loor), the USDA Cooperative State Research, Education, and Extension Service (Washington, DC) and the Illinois Agricultural Experiment Station (Urbana) through multistate project number W-1181 (James Drackley), and work supported by the Cooperative State Research Service, USDA, under project no. NE 1028 (Dawn Morin). The authors thank the Mitchell Fellowship in Animal Nutrition, University of Illinois, for financial support for Kasey M. Moyes 2007 to 2008; Joseph Hogan, The Ohio State University, for providing the Strep. uberis (O140J) isolate used for this study; and Janice Bahr, University of Illinois, for her technical assistance with validation of ELISA. In addition, gratitude is extended to the University of Illinois Dairy Research Unit staff, Walter Hurley, Dave Carlson, Nicole Janovick, Jennifer Stamey, Daniel Graugnard, and Karen Fried for assistance with animal care and data collection.

\section{REFERENCES}

Ametaj, B. N., B. J. Bradford, G. Bobe, R. A. Nafikov, Y. Lu, J. W. Young, and D. C. Beitz. 2005. Strong relationships between mediators of the acute phase response and fatty liver in dairy cows. Can. J. Anim. Sci. 85:165-175.

AOAC. 1995. Official Methods of Analysis. 16th ed. Assoc. Off. Anal. Chem., Arlington, VA.

Bannerman, D. D., M. J. Paape, J. P. Goff, K. Kimura, J. D. Lippolis, and J. C. Hope. 2004. Innate immune response to IM infection with Serratia marcescens and Streptococcus uberis. Vet. Res. 35:681-700.

Baumberger, C., R. J. Ulevitch, and J. M. Dayer. 1991. Modulation of endotoxic activity of lipopolysaccharide by high-density lipoprotein. Pathobiology 59:378-383.

Bertoni, G., E. Trevisi, X. Han, and M. Bionaz. 2008. Effects of inflammatory conditions on liver activity in puerperium period and consequences for performance in dairy cows. J. Dairy Sci. 91:3300-3310.

Bionaz, M., E. Trevisi, L. Calamari, F. Librandi, A. Ferrari, and G. Bertoni. 2007. Plasma paraoxonase, health, inflammatory conditions, and liver function in transition dairy cows. J. Dairy Sci. 90:1740-1750

Burvenich, C., M. J. Paape, D. Hoeben, H. Dosogne, A. M. MassartLeen, and J. Blum. 1999. Modulation of the inflammatory reaction and neutrophil defense of the bovine lactating mammary gland by growth hormone. Domest. Anim. Endocrinol. 17:149-159.

Cai, T. Q., P. G. Weston, L. A. Lund, B. Brodie, D. J. McKenna, and W. C. Wagner. 1994. Association between neutrophil functions and periparturient disorders in cows. Am. J. Vet. Res. 55:934-943.

Calder, P. C., J. A. Bond, D. J. Harvey, S. Gordon, and E. A. Newsholme. 1990. Uptake and incorporation of saturated and unsaturated fatty acids into macrophage lipids and their effect upon macrophage adhesion and phagocytosis. J. Biochem. 269:807-814.

Dann, H. M., N. B. Litherland, J. P. Underwood, M. Bionaz, A. D'Angelo, J. W. McFadden, and J. K. Drackley. 2006. Diets during far-off and close-up dry periods affect periparturient metabolism and lactation in multiparous cows. J. Dairy Sci. 89:3563-3577.

Drackley, J. K. 1999. Biology of dairy cows during the transition period: The final frontier? J. Dairy Sci. 82:2259-2273.

Grönlund, U., C. Hulten, P. D. Eckersall, C. Hogarth, and K. Persson Waller. 2003. Haptoglobin and serum amyloid A in milk and serum 
during acute and chronic experimentally induced Staphylococcus aureus mastitis. J. Dairy Res. 70:379-386.

Guo, J., R. R. Peters, and R. A. Kohn. 2007. Effect of a transition diet on production performance and metabolism in periparturient dairy cows. J. Dairy Sci. 90:5247-5258.

Hoeben, D., C. Burvenich, P. J. Eppard, J. C. Byatt, and D. L. Hard. 1999. Effect of bovine somatotropin on neutrophil functions and clinical symptoms during Streptococcus uberis mastitis. J. Dairy Sci. 82:1465-1481.

Hoeben, D., R. Heyneman, and C. Burvenich. 1997. Elevated levels of beta-hydroxybutyric acid in periparturient cows and in vitro effect on respiratory burst activity of bovine neutrophils. Vet. Immunol. Immunopathol. 58:165-170.

Jánosi, S., M. Kulcsár, P. Kóródi, L. Kátai, J. Reiczigel, S. J. Dieleman, J. A. Nikolic, G. Sályi, P. Ribiczey-Szabó, and G. Huszenicza. 2003 Energy imbalance related predisposition to mastitis in group-fed high-producing postpartum dairy cows. Acta Vet. Hung. 51:409 424

Jayarao, B. M., B. E. Gillespie, M. J. Lewis, H. H. Dowlen, and S. P. Oliver. 1999. Epidemiology of Streptococcus uberis IM infections in a dairy herd. J. Vet. Med. 46:433-442.

Kluciński, W., A. Degórski, E. Miernik-Degórska, S. Targowski, and A. Winnicka. 1988. Effect of ketone bodies on the phagocytic activity of bovine milk macrophages and polymorphonuclear leukocytes. J. Vet. Med., Ser. A. 35:632-639.

Kremer, W. D. J., E. N. Noordhuizen-Stassen, F. J. Grommers, Y. H. Schukken, R. Heeringa, A. Brand, and C. Burvenich. 1993. Severity of experimental Escherichia coli mastitis in ketonemic and nonketonemic dairy cows. J. Dairy Sci. 76:3428-3436.

Mehrzad, J., H. Dosogne, E. Meyer, R. Heyneman, and C. Burvenich. 2001. Respiratory burst activity of blood and milk neutrophils in dairy cows during different stages of lactation. J. Dairy Res. 68:399-415.

Morin, D., C. Mallard, T. Auchtung, and G. Dahl. 2003. Response to experimentally-induced Streptococcus uberis mastitis in cows exposed to long or short day photoperiod during the dry period. Page 336 in Proc. Natl. Mastitis Council Ann. Meeting. Natl. Mastitits Counc., Madison, WI.

Morin, D. E., R. D. Shanks, and G. C. McCoy. 1998. Comparison of antibiotic administration in conjunction with supportive measures versus supportive measures alone for treatment of dairy cows with clinical mastitis. J. Am. Vet. Med. Assoc. 213:676-684.

National Mastitis Council. 2004. Microbiological Procedures for Use in the Diagnosis of Bovine Udder Infection and Determination of Milk Quality. 4th ed. Natl. Mast. Counc., Verona, WI.

NRC. 2001. Nutrient Requirements of Dairy Cattle. 7th rev. ed. Natl. Acad. Sci., Washington, DC.

Nyman, A.-K., U. Emanuelson, K. Holtenius, K. L. Ingvartsen, T. Larsen, and K. Persson Waller. 2008. Metabolites and immune variables associated with somatic cell counts of primiparous dairy cows. J. Dairy Sci. 91:2996-3009.

Oh, S. K., N. Pavlotsky, and A. I. Tauber. 1990. Specific binding of haptoglobin to human neutrophils and its functional consequences. J. Leukoc. Biol. 47:142-148.

Perkins, K. H., M. J. Vandehaar, J. L. Burton, J. S. Liesman, R. J. Erskine, and T. H. Elsasser. 2002. Clinical responses to IM endotoxin infusion in dairy cows subjected to feed restriction. J. Dairy Sci. 85:1724-1731.

Pedersen, L. H., B. Aalbæk, C. M. Røntved, K. L. Ingvartsen, N. S. Sorensen, P. M. Heegaard, and H. E. Jensen. 2003. Early pathogenesis and inflammatory response in experimental bovine mastitis due to Streptococcus uberis. J. Comp. Pathol. 128:156164.

Petersen, H. H., J. P. Nielsen, and P. M. Heegaard. 2004. Application of acute phase protein measurements in veterinary clinical chemistry. Vet. Res. 35:163-187.

Pithon-Curi, T. C., M. P. De Melo, and R. Curi. 2004. Glucose and glutamine utilization by rat lymphocytes, monocytes, and neutrophils in culture: A comparative study. Cell Biochem. Funct. 22:321-326.

Rainard, P., and C. Riollet. 2006. Innate immunity of the bovine mammary gland. Vet. Res. 37:369-400.

Rastani, R. R., S. M. Andrew, S. A. Zinn, and C. J. Sniffen. 2001. Body composition and estimated tissue energy balance in Jersey and Holstein cows during early lactation. J. Dairy Sci. 84:12011209.

Salas-Salvadó, J., M. Bulló, P. García-Lorda, R. Figueredo, D. Del Castillo, A. Bonada, and R. Balanzà. 2006. Subcutaneous adipose tissue cytokine production is not responsible for the restoration of systemic inflammation markers during weight loss. Int. J. Obes. (Lond.) 30:1714-1720.

SAS Institute. 2003. SAS User's Guide: Statistics, Version 9.1 Edition. SAS Inst. Inc., Cary, NC.

Seifi, H. A., B. Dalir-Naghadeh, N. Farzaneh, M. Mohri, and M. GorjiDooz. 2007. Metabolic changes in cows with or without retained fetal membranes in transition period. J. Vet. Med. A 54:92-97.

Smits, E., C. Burvenich, A. J. Guidry, and E. Roets. 1998. In vitro expression of adhesion receptors and diapedesis by polymorphonuclear neutrophils during experimentally induced Streptococcus uberis mastitis. Infect. Immun. 66:2529-2534.

Studer, V. A., R. R. Grummer, S. J. Bertics, and C. K. Reynolds. 1993. Effect of prepartum propylene glycol administration on periparturient fatty liver in dairy cows. J. Dairy Sci. 76:29312939

Suojala, L., T. Orro, H. Järvinen, J. Saatsi, and S. Pyörälä. 2008. Acute phase response in two consecutive experimentally induced E. coli intramammary infections in dairy cows. Acta Vet. Scand. 50:18-28.

Suriyasathaporn, W., A. J. J. M. Daemen, E. N. NoordhuizenStassen, and Y. H. Schukken. 1999. Beta-hydroxybutyrate levels in peripheral blood and ketone bodies supplemented in culture media affect the in vitro chemotaxis of bovine leukocytes. Vet. Immunol. Immunopathol. 68:177-186.

Tempelman, R. J. 2005. Assessing statistical precision, power, and robustness of alternative experimental designs for two color microarray platforms based on mixed effects models. Vet. Immunol. Immunopathol. 105:175-186.

Van Merris, V., E. Meyer, L. Duchateau, J. Blum, and C. Burvenich. 2004. All-trans retinoic acid is increased in the acute phase-related hyporetinemia during Escherichia coli mastitis. J. Dairy Sci 87:980-987.

Waldron, M. R., A. E. Kulick, A. W. Bell, and T. R. Overton. 2006. Acute experimental mastitis is not causal toward the development of energy-related metabolic disorders in early postpartum dairy cows. J. Dairy Sci. 89:596-610.

Walsh, R. B., J. S. Walton, D. F. Kelton, S. J. LeBlanc, K. E. Leslie, and T. F. Duffield. 2007. The effect of subclinical ketosis in early lactation on reproductive performance of postpartum dairy cows. J. Dairy Sci. 90:2788-2796.

Wellnitz, O., and D. E. Kerr. 2004. Cryopreserved bovine mammary cells to model epithelial response to infection. Vet. Immunol. Immunopathol. 101:191-202. 